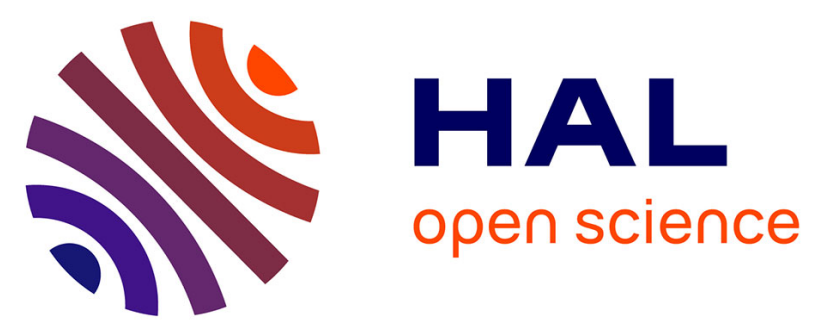

\title{
A combined experimental and theoretical study of the thermal $[3+2]$ cycloaddition of carbonyl ylides with activated alkenes
}

Samira Hamza-Reguig, Ghenia Bentabed-Ababsa, Luis R Domingo, Mar Ríos-Gutiérrez, Stephanie Philippot, Stéphane Fontanay, Raphaël E. Duval, Sandrine Ruchaud, Stéphane Bach, Thierry Roisnel, et al.

\section{To cite this version:}

Samira Hamza-Reguig, Ghenia Bentabed-Ababsa, Luis R Domingo, Mar Ríos-Gutiérrez, Stephanie Philippot, et al.. A combined experimental and theoretical study of the thermal $[3+2]$ cycloaddition of carbonyl ylides with activated alkenes. Journal of Molecular Structure, 2018, 1157, pp.276-287. 10.1016/j.molstruc.2017.12.052 . hal-01695551v2

\section{HAL Id: hal-01695551 \\ https://hal.univ-lorraine.fr/hal-01695551v2}

Submitted on 26 Nov 2018

HAL is a multi-disciplinary open access archive for the deposit and dissemination of scientific research documents, whether they are published or not. The documents may come from teaching and research institutions in France or abroad, or from public or private research centers.
L'archive ouverte pluridisciplinaire HAL, est destinée au dépôt et à la diffusion de documents scientifiques de niveau recherche, publiés ou non, émanant des établissements d'enseignement et de recherche français ou étrangers, des laboratoires publics ou privés. 


\section{Graphical Abstract}

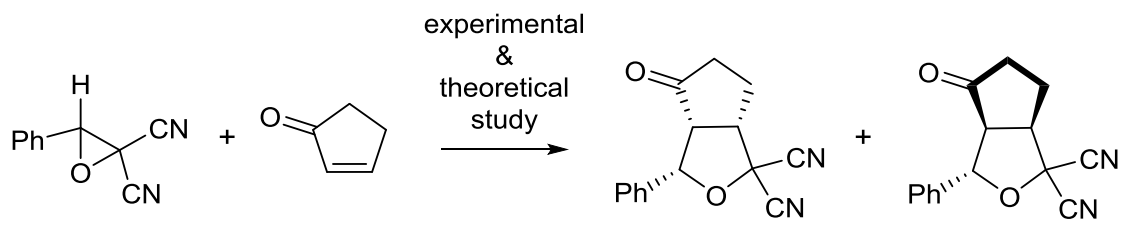

\section{A combined experimental and theoretical study of the thermal [3+2] cycloaddition of carbonyl ylides with activated alkenes}

Samira Hamza-Reguig, ${ }^{\mathrm{a}}$ Ghenia Bentabed-Ababsa, ${ }^{\mathrm{a}, \mathrm{b}, *}$ Luis R. Domingo, ${ }^{\mathrm{c}, *}$ Mar Ríos-Gutiérrez, ${ }^{\mathrm{c}}$ Stéphanie Philippot, ${ }^{\mathrm{d}}$ Stéphane Fontanay, ${ }^{\mathrm{d}}$ Raphaël E. Duval, ${ }^{\mathrm{d}, *}$ Sandrine Ruchaud, ${ }^{\mathrm{e}}$ Stéphane Bach, ${ }^{\mathrm{e}, *}$ Thierry Roisnel, ${ }^{\mathrm{f}}$ and Florence Mongin ${ }^{\mathrm{b}, *}$

${ }^{a}$ Laboratoire de Synthèse Organique Appliquée, Faculté des Sciences Exactes et Appliquées, Université d'Oran 1 Ahmed Ben Bella, BP 1524 El M'Naouer, 31000 Oran, Algeria

${ }^{\mathrm{b}}$ Chimie Organique et Interfaces, Institut des Sciences Chimiques de Rennes, UMR 6226, CNRS-Université de Rennes 1, Bâtiment 10A, Case 1003, Campus de Beaulieu, 35042 Rennes, France

${ }^{\mathrm{c}}$ Department of Organic Chemistry, University of Valencia, Dr. Moliner 50, 46100 Burjassot, Valencia, Spain

${ }^{\mathrm{d}}$ UMR 7565, SRSMC, CNRS-Université de Lorraine, Faculté de Pharmacie, 5 rue Albert Lebrun, BP 80403, 54001 Nancy, France

e Sorbonne Universités, UPMC Univ Paris 06, CNRS USR3151, "Protein Phosphorylation and Human Disease" Unit, Plateforme de criblage KISSf, Station Biologique de Roscoff, Place Georges Teissier, 29688 Roscoff, France

${ }^{\mathrm{f}}$ Centre de Diffractométrie X, Institut des Sciences Chimiques de Rennes, UMR 6226, CNRSUniversité de Rennes 1, Bâtiment 10B, Campus de Beaulieu, 35042 Rennes, France

* Corresponding authors. E-mail addresses:

badri_sofi@yahoo.fr (G. Bentabed-Ababsa), domingo@utopia.uv.es (L. R. Domingo), raphael.duval@univ-lorraine.fr(R.E.Duval), bach@sb-roscoff.fr (S. Bach), florence.mongin@univ-rennes1.fr (F. Mongin). 


\begin{abstract}
:
4-Benzoyl-3,5-diaryltetrahydrofuran-2,2-dicarbonitriles were first synthesized from 2,2dicyano-3-aryloxiranes and chalcones at toluene reflux; the 4,5-cis products proved to be predominantly formed and were isolated. Whereas shortened reaction times were observed by using microwave irradiation or catalytic cuprous chloride, no significant stereoselectivity change was in general noticed. Reacting 2,2-dicyano-3-aryloxiranes with 2-cyclopentenone next afforded 3-aryl-4-oxohexahydro-1 $H$-cyclopenta[c]furan-1,1-dicarbonitriles, and the endo stereoisomers were isolated. That no stereoselectivity change was noticed in the presence of cuprous chloride rather suggests an impact of the salt on the epoxide ring opening. Finally, treatment of 2,2-dicyano-3-aryloxiranes by 2-morpholinoacrylonitrile yielded 3-cyano-3morpholino-5-phenyltetrahydrofuran-2,2-dicarbonitriles from which the preponderant trans isomers were isolated. Importantly, the molecular mechanism of the domino reaction between 2,2-dicyano-3-phenyloxirane and 2-cyclopentenone was studied. The rate-determining thermal ring opening of the oxirane is followed by a non-concerted pseudoradical-type reaction of the carbonyl ylide with 2-cyclopentenone. Using the bond evolution theory also allowed the regioselectivity of this non-polar reaction to be explained.
\end{abstract}

Keywords: [3+2] cycloaddition; carbonyl ylides; enones; enamines; tetrahydrofurans; theoretical calculations

\title{
1. Introduction
}

Tetrahydrofurans are found in various natural products, and many of these heterocyclecontaining products show potent biological activities. ${ }^{1}$ Consequently, the synthesis of tetrahydrofuran derivatives has attracted great attention due to their wide applications, notably in medicinal industry. ${ }^{2}$ 
[3+2] Cycloaddition (32CA) reactions, whose general concept was introduced by Huisgen and co-workers in 1960s, ${ }^{3}$ have been established as one of the most powerful methods for the construction of oxygen-containing heterocycles ${ }^{4}$ and led to combined experimental and theoretical studies in order to understand their underlying principles. ${ }^{5}$ Carbonyl ylides (CYs), generated by thermal ring opening of epoxides, are known to react with multiple bonds of alkynes, ${ }^{6}$ alkenes, ${ }^{6 \mathrm{a}, \mathrm{b}, 7}$ imines, ${ }^{8}$ aldehydes ${ }^{8 \mathrm{c}, \mathrm{d}, 9}$ ketones $^{10}$ and thioketones, ${ }^{11}$ affording highly substituted dihydrofurans, tetrahydrofurans, oxazolidines, dioxolanes and oxathiolanes, respectively. In general, CYs are three-atom-components that react very quickly with either species containing a multiple bond, both in non-polar and polar pseudodiradical-type 32CA reactions with very low activation energies, below $1 \mathrm{kcal} \cdot \mathrm{mol}^{-1} \cdot{ }^{12}$

We previously performed studies on 32CA reactions between CYs generated by thermal ring opening of epoxides, on the one hand, and aldehydes, ${ }^{8 \mathrm{~d}}$ imines, ${ }^{8 \mathrm{~d}}$ ketones ${ }^{10}$ and alkynes, ${ }^{6 \mathrm{~g}}$ on the other hand. In particular, we investigated the mechanisms of these reactions through theoretical calculations using density functional theory (DFT) methods. In order to extend the knowledge on reactions involving such CYs, we studied the reactivity of these CYs toward enones (impact of microwave irradiation and presence of a Lewis acid) and enamines. More importantly, through suitable calculations, we could get important information on the pathway by which the cycloadducts are formed, and rationalize the regioselectivity observed.

\section{Results and Discussion}

\subsection{Synthetic aspects}

We considered 32CA reactions between the different 2,2-dicyano-3-aryloxiranes 1a-c and chalcones 2a-c (Table 1). The reactions carried out in refluxing toluene and monitored by NMR (by taking samples from the reaction mixtures) afforded 4-benzoyl-3,5diphenyltetrahydrofuran-2,2-dicarbonitriles. Under classical heating in the absence of 
catalyst, the reactions were completed in times ranging from $24 \mathrm{~h}$ to $62 \mathrm{~h}$; the presence of an electron-donating group (OMe) at the 4 position of the chalcone phenyl group favors the reaction (entries 5, 6, 12 and 13), as well as the presence of an electron-donating group (OMe) at the 4 position of the epoxide phenyl group (entries 8-13).

Table 1. Cycloaddition reaction between CYs generated from the epoxides $\mathbf{1}$ and chalcones 2.

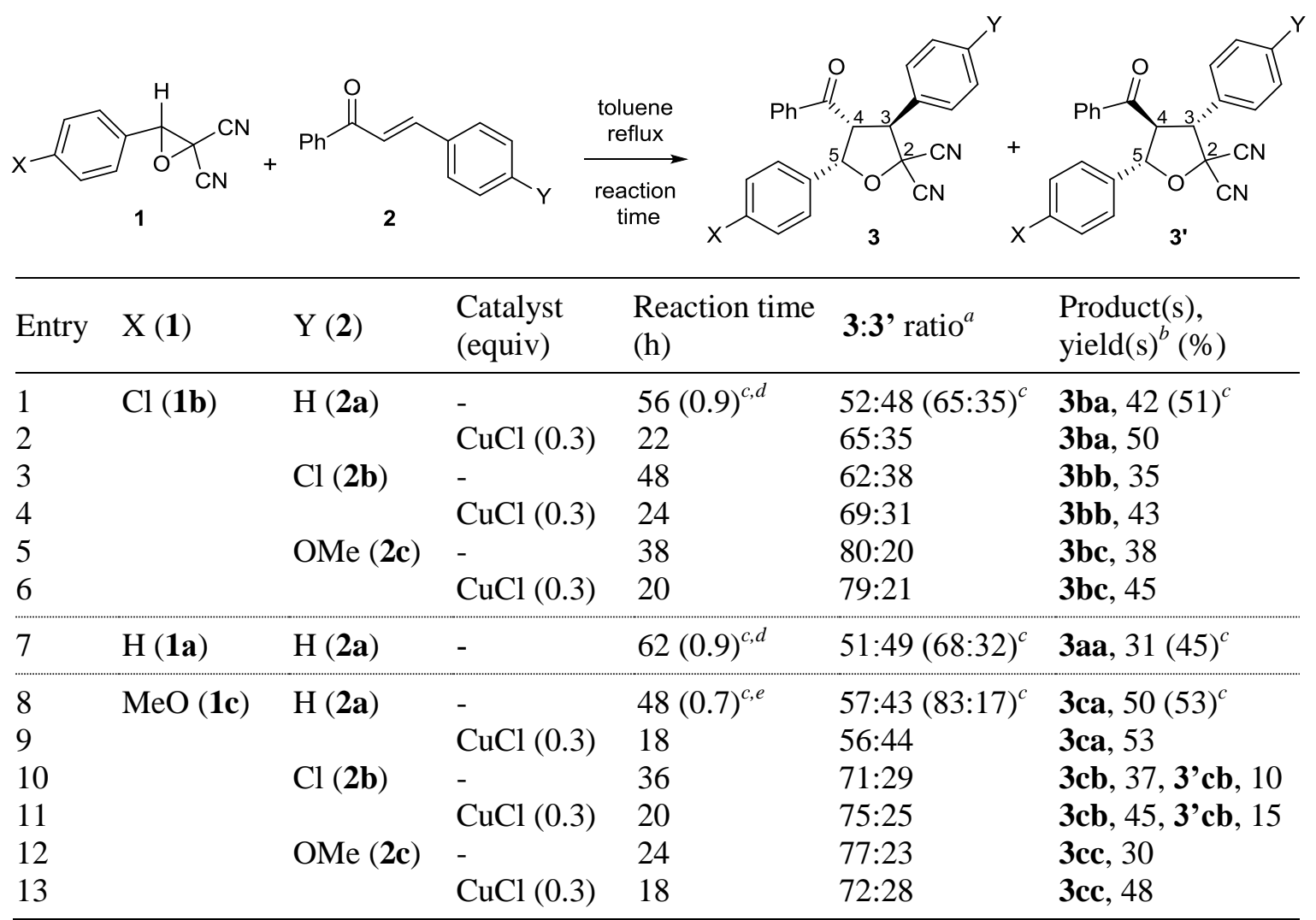

${ }^{a}$ Determined from the ${ }^{1} \mathrm{H}$ NMR spectra of the crude. ${ }^{b}$ After purification by column chromatography. ${ }^{c}$ The values in brackets correspond to reactions performed without solvent with recourse to microwave irradiation $(120 \mathrm{~W}) \cdot{ }^{d} 6 \mathrm{~min}$ to reach $80^{\circ} \mathrm{C}, 9$ min to reach $120^{\circ} \mathrm{C}$, and maintain at $120^{\circ} \mathrm{C}$ for 40 min. ${ }^{e} 3 \mathrm{~min}$ to reach $60{ }^{\circ} \mathrm{C}, 6 \mathrm{~min}$ to reach $80^{\circ} \mathrm{C}$, and maintain at $80^{\circ} \mathrm{C}$ for $35 \mathrm{~min}$.

In order to reduce the reaction times required for these cycloaddition reactions, we performed experiments involving the epoxides 1a-c and chalcone (2a) using microwave irradiation $^{13}$ at different powers and irradiation times. The best results were obtained without solvent $($ power $=120 \mathrm{~W}$ ), with shortened reaction times in comparison to the corresponding reactions in toluene at reflux (55 min instead of $56 \mathrm{~h}$ for 3(')ba (entry 1), $55 \mathrm{~min}$ instead of 62 $\mathrm{h}$ for 3(')aa (entry 7), and $44 \mathrm{~min}$ instead of $48 \mathrm{~h}$ for 3(')ca (entry 8 ). 
If cuprous chloride has been recognized as a suitable catalyst for Huisgen's type reactions giving 1,2,3-triazoles from azides and alkynes, ${ }^{15}$ its use to catalyze other 1,3-dipolar cycloadditions is far from common. In the present case, shortened reaction times were noticed for all the tested substrates by using 0.3 equivalent of this salt (Table 1 ).

As evidenced by recording the ${ }^{1} \mathrm{H}$ NMR spectra of the crudes, the 4,5-cis products 3 were formed preponderantly in all the reactions whereas the 4,5-trans products 3' could not be avoided. The former were all isolated by column chromatography over silica gel in yields ranging from 30 to $53 \%$ (Table 1) whereas the latter were only separated similarly in the case of 3'cb (10-15\% yield, entries 10 and 11). If microwave irradiation tends to favor the formation of the 4,5-cis products $\mathbf{3}$ in the case of $\mathbf{2 a}$, the impact of cuprous chloride on the stereoselectivity is less obvious.

$\mathrm{HMBC}$ and $\mathrm{HMQC}$ sequences were performed on $\mathrm{CDCl}_{3}$ solution of the product $\mathbf{3 b a}$ in order to assign the ${ }^{1} \mathrm{H}$ and ${ }^{13} \mathrm{C}$ NMR signals (see Supplementary data). The NOESY experiment showed a relationship between $\mathrm{H} 4$ (triplet at $5.13 \mathrm{ppm}$, coupling constant of 11 $\mathrm{Hz}$ ) and $\mathrm{H} 5$ (doublet at $5.95 \mathrm{ppm}$, coupling constant of $9.6 \mathrm{~Hz}$ ), but no relationship between $\mathrm{H} 4$ and $\mathrm{H} 3$ (doublet at $4.89 \mathrm{ppm}$, coupling constant of $11.5 \mathrm{~Hz}$ ), in accordance with the structure proposed for $\mathbf{3 b a}$ (concerning numbering, see Table 1). In addition, suitable crystals for X-ray diffraction of the minor diastereoisomer 3'ca could be obtained, and allowed us to identify unequivocally its structure (Figure 1, left).

Figure 1. ORTEP diagram (30\% probability) of 3'ca and $\mathbf{5 a}$.
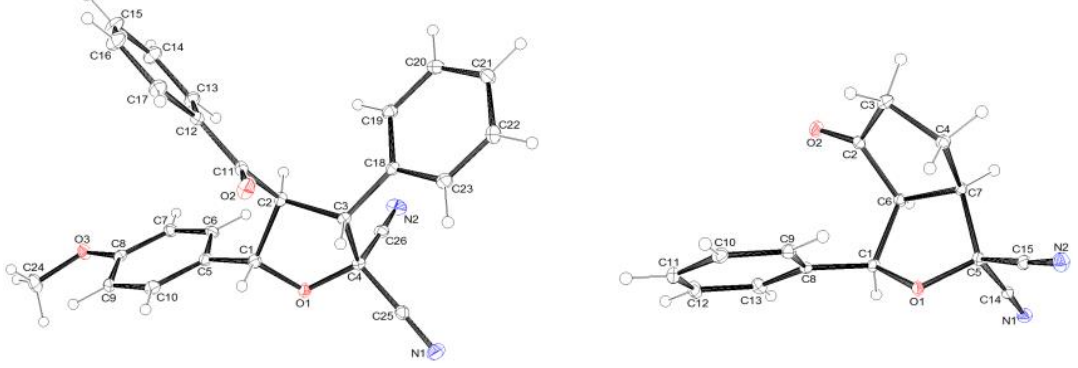
We next turned to the reaction of the 2,2-dicyano-3-aryloxiranes 1a-c with 2cyclopentenone (4) (Table 2). In refluxing toluene, two cycloadducts were formed regioselectively in reaction times ranging from $25 \mathrm{~h}$ (with the more reactive epoxide $1 \mathrm{c}$, entry 4) to $48 \mathrm{~h}$ (entry 1). The presence of cuprous chloride allowed the reaction times to be shortened, but did not modify significantly the stereoisomeric ratios (entries 2 and 5); this result is rather in agreement with an impact of the salt on the epoxide ring opening step of the reaction. Whereas Lewis acids such as $\mathrm{BF}_{3}$ or $\mathrm{AlCl}_{3}$ favor the ring aperture of epoxides by heterolytic rupture of their $\mathrm{C}-\mathrm{O}$ bond to give zwitterionic species, the copper catalyst could favor the homolytic rupture of their $\mathrm{C}-\mathrm{C}$ bond, yielding a carbonyl ylide (see Part 2.2).

In all the attempted reactions, the endo stereoisomers $\mathbf{5}$ were found to slightly predominate over the exo ones 5'. Whereas the endo $\mathbf{5 a}$ and $\mathbf{5 b}$ were isolated by column chromatography over silica gel in about 50\% yield (entries 1-3), the exo 5'b and 5'c were separated similarly in about $25 \%$ yield (entries 1, 4 and 5 ).

Table 2. Cycloaddition reaction between CYs generated from the epoxides $\mathbf{1}$ and 2cyclopentenone (4).

\begin{tabular}{|c|c|c|c|c|c|}
\hline Entry & $\mathrm{X}(\mathbf{1})$ & $\begin{array}{l}\text { Catalyst } \\
\text { (equiv) }\end{array}$ & $\begin{array}{l}\text { Reaction time } \\
\text { (h) }\end{array}$ & 5:5' ratio $^{a}$ & $\begin{array}{l}\text { Product(s), } \\
\text { yield(s) }^{b}(\%)\end{array}$ \\
\hline 1 & $\mathrm{Cl}(\mathbf{1} \mathbf{b})$ & - & 48 & $60: 40$ & $\mathbf{5 b}, 45, \mathbf{5} ' \mathbf{b}, 23$ \\
\hline 2 & & $\mathrm{CuCl}(0.3)$ & 24 & $57: 43$ & $\mathbf{5 b}, 50$ \\
\hline 3 & $\mathrm{H}(\mathbf{1 a})$ & - & 46 & $59: 41$ & $\mathbf{5 a}, 51$ \\
\hline 4 & $\mathrm{MeO}(\mathbf{1 c})$ & - & 25 & $57: 43$ & $5 ' \mathbf{c}, 23^{c}$ \\
\hline 5 & & $\mathrm{CuCl}(0.3)$ & 18 & $62: 38$ & $5 ' \mathbf{c}, 29^{c}$ \\
\hline
\end{tabular}

${ }^{a}$ Determined from the ${ }^{1} \mathrm{H}$ NMR spectra of the crude mixture. ${ }^{b}$ After purification by column chromatography. ${ }^{c}$ Attempts to isolate pure $\mathbf{5 c}$ failed; estimated yields of $\mathbf{5}$ 'c were given due to $\sim 10 \%$ remaining $\mathbf{5 c}$. 
Two-dimension NMR sequences were performed as before on a $\mathrm{CDCl}_{3}$ solution of the products $\mathbf{5 b}$ and $\mathbf{5}^{\prime} \mathbf{b}$. After assignment of the ${ }^{1} \mathrm{H}$ and ${ }^{13} \mathrm{C}$ NMR signals, the performed NOESY experiment evidenced a relationship between $\mathrm{H} 4$ (triplet at $3.36 \mathrm{ppm}(8.6 \mathrm{~Hz})$ and triplet at $3.24 \mathrm{ppm}(7.8 \mathrm{~Hz}$ ), respectively) and $\mathrm{H} 3$ (signals at 3.68-3.81 ppm) for both $\mathbf{5 b}$ and 5'b, as expected. Correlations between $\mathrm{H} 4$ and $\mathrm{H} 5$ (doublet at $5.52 \mathrm{ppm}(9.1 \mathrm{~Hz})$ and doublet at $5.34 \mathrm{ppm}(6.7 \mathrm{~Hz})$, respectively) were also identified for both $\mathbf{5 b}$ and $\mathbf{5} \mathbf{b}$, albeit to a smaller extent in the case of the minor stereoisomer. Importantly, correlation between $\mathrm{H} 3$ and H5 was only detected in the case of the predominant stereoisomer, in accordance with an endo arrangement (stereoisomer 5b). Finally, suitable crystals for X-ray diffraction of the major stereoisomer 5a could be obtained, allowing us to elucidate unambiguously its structure (Figure 1, right).

The 2,2-dicyano-3-aryloxiranes 1a-c were reacted with 2-morpholinoacrylonitrile (9) in refluxing toluene. 3-Cyano-3-morpholino-5-phenyltetrahydrofuran-2,2-dicarbonitriles were obtained. As expected due to the presence of the electron-withdrawing group, the oxirane 1d is less reactive, and is only converted similarly in refluxing xylene (Table 3).

Table 3. Cycloaddition reaction between CYs generated from the epoxides 1 and 2morpholinoacrylonitrile (9).

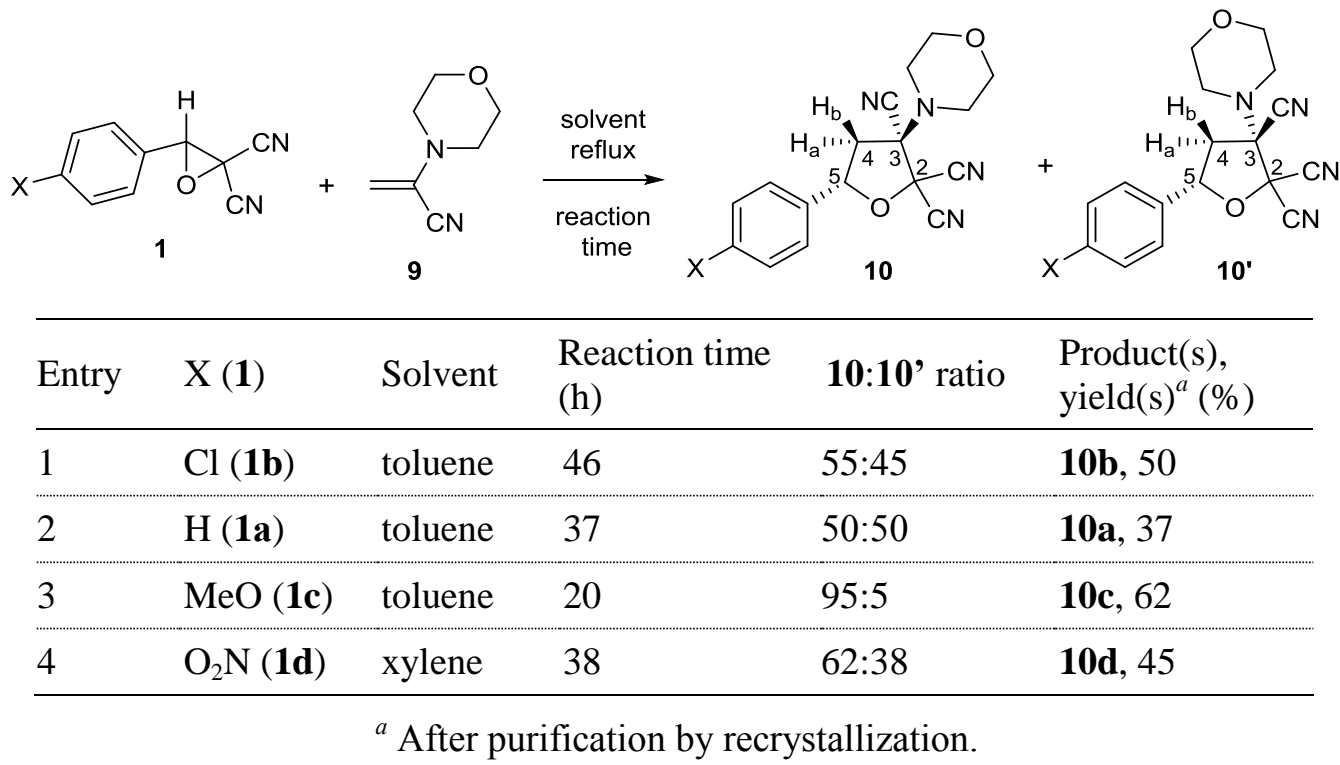


Recording the ${ }^{1} \mathrm{H}$ NMR spectra of the crudes led to two sets of peaks. The preponderant trans products $\mathbf{1 0}$ were isolated from the mixture by recrystallization from ethanol in yields ranging from $37 \%$ to $62 \%$ (Table 3). From NMR data gathered from closely related 5phenyltetrahydrofurans unsubstituted at their 4 position, ${ }^{16}$ one could estimate the cis and trans coupling constants values between $\mathrm{H} 4$ and $\mathrm{H} 5$ at $\sim 6-7 \mathrm{~Hz}$ and $\sim 10-11 \mathrm{~Hz}$, respectively, and the assignment of $\mathrm{H}_{\mathrm{a}}$ and $\mathrm{H}_{\mathrm{b}}$ of $\mathbf{1 0}$ was made on this basis. Next, in the absence of structural proof, we assumed a more downfield signal for the proton closer to the nitrile function $\left(\mathrm{H}_{\mathrm{a}}\right.$ for 10), ${ }^{17}$ and attributed the main sets of peaks of the crudes to $\mathbf{1 0}$.

\subsection{Theoretical aspects}

Recent molecular electron density theory ${ }^{18}$ studies devoted to $32 \mathrm{CA}$ reactions have established a very good correlation between the electronic structure of three-atomcomponents and their reactivity toward ethylene. ${ }^{19}$ Thus, depending on their electronic structure, the non-polar 32CA reactions were classified into pseudodiradical-type ( $p d r$ type), ${ }^{19}$ pseudoradical-type (pmr-type), ${ }^{19 b}$ carbenoid-type $(\text { cb-type })^{20}$ and zwitterionic-type $(z w \text {-type })^{19 a}$ reactions. The reactivity trend decreases in the following order: pseudodiradical > pseudoradical $>$ carbenoid $>$ zwitterionic. The simplest azomethine ylide (AY) and CY have a pseudodiradical structure that enables them to react quickly in non-polar pdr-type reactions (see Scheme 1). ${ }^{19 a}$ However, the substitution in these three-atom-components can modify their electronic structure, and consequently their reactivity. ${ }^{12}$

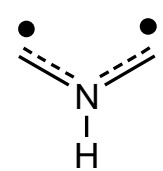

AY

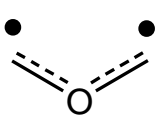

CY

Scheme 1. Pseudodiradical structures of the simplest azomethine ylide (AY) and CY. 
In order to explain the molecular mechanism of these domino reactions, the reaction between the oxirane 1a and smaller electron-deficient 2-cyclopentenone (4), yielding the tetrahydrofurans 5(')a and 6(')a, was theoretically studied using DFT methods. This theoretical study has been divided into two parts: (i) first, reaction paths associated with the domino reaction between the oxirane 1a and 2-cyclopentenone (4) were explored and characterized; and (ii) then, a bonding evolution theory ${ }^{21}$ study along the most favorable reactive channel associated with the 32CA between CY 8 and 2-cyclopentenone (4) was performed in order to characterize the molecular mechanism of these $32 \mathrm{CA}$ reactions.

\subsubsection{Analysis of the reaction paths associated with the domino reaction between the oxirane 1a and 2-cyclopentenone (4)}

The reaction between the oxirane 1a and 2-cyclopentenone (4) is a domino process that comprises two sequential reactions: (i) first, the thermal ring opening of the oxirane 1a to yield CY 8 and (ii) second, the 32CA reaction of CY 8 with 2-cyclopentenone (4) to give the tetrahydrofurans 5(')a and 6(')a. In order to explain the reactivity and the selectivities of this domino reaction, its energetic and geometrical aspects were theoretically studied within the molecular electron density theory, ${ }^{18}$ using DFT calculations at the MPWB1K/6-311G(d) computational level. Total and relative electronic energies, in gas phase and in toluene, of the stationary points involved in the two processes are given in Table S2 of the Supplementary data, relative enthalpies and Gibbs free energies are displayed in Scheme 2 and complete thermodynamic data are gathered in Table S3.

The thermal ring opening of the oxirane 1a to yield CY 8 takes place through a one-step mechanism with a very high activation enthalpy, $33.0 \mathrm{kcal} \cdot \mathrm{mol}^{-1}$ (TS-o), the reaction being strongly endothermic by $20.1 \mathrm{kcal} \cdot \mathrm{mol}^{-1}$. Once CY 8 is formed, it can adopt the $E$ or $Z$ configuration through the restricted rotation of the $\mathrm{O} 2-\mathrm{C} 3$ bond. In this way, while $(E)-\mathbf{8}$ 
presents a planar arrangement, $(Z)-\mathbf{8}$ is twisted as a consequence of the steric hindrance between the phenyl substituent and one cyano group. As this hindrance makes $(Z)-\mathbf{8}$ notably higher in energy than $(E)-8\left(7.6 \mathrm{kcal} \cdot \mathrm{mol}^{-1}\right)$, only the $E$ configuration of CY 8 is considered in the present study. The Electron Localization Function (ELF) topological analysis of the electron density of CY 8 indicates that this three-atom-component has a pseudoradical structure (see $(E)-8$ in Scheme 2 and the ELF analysis in the Supplementary data). Note that the presence of the phenyl substituent at the C3 carbon of CY 8 causes the delocalization of one of the two pseudoradical centers present in the simplest CY (see Scheme 1). Consequently, it is expected that CY 8 participates in pmr-type 32CA reactions. ${ }^{19 \mathrm{~b}}$
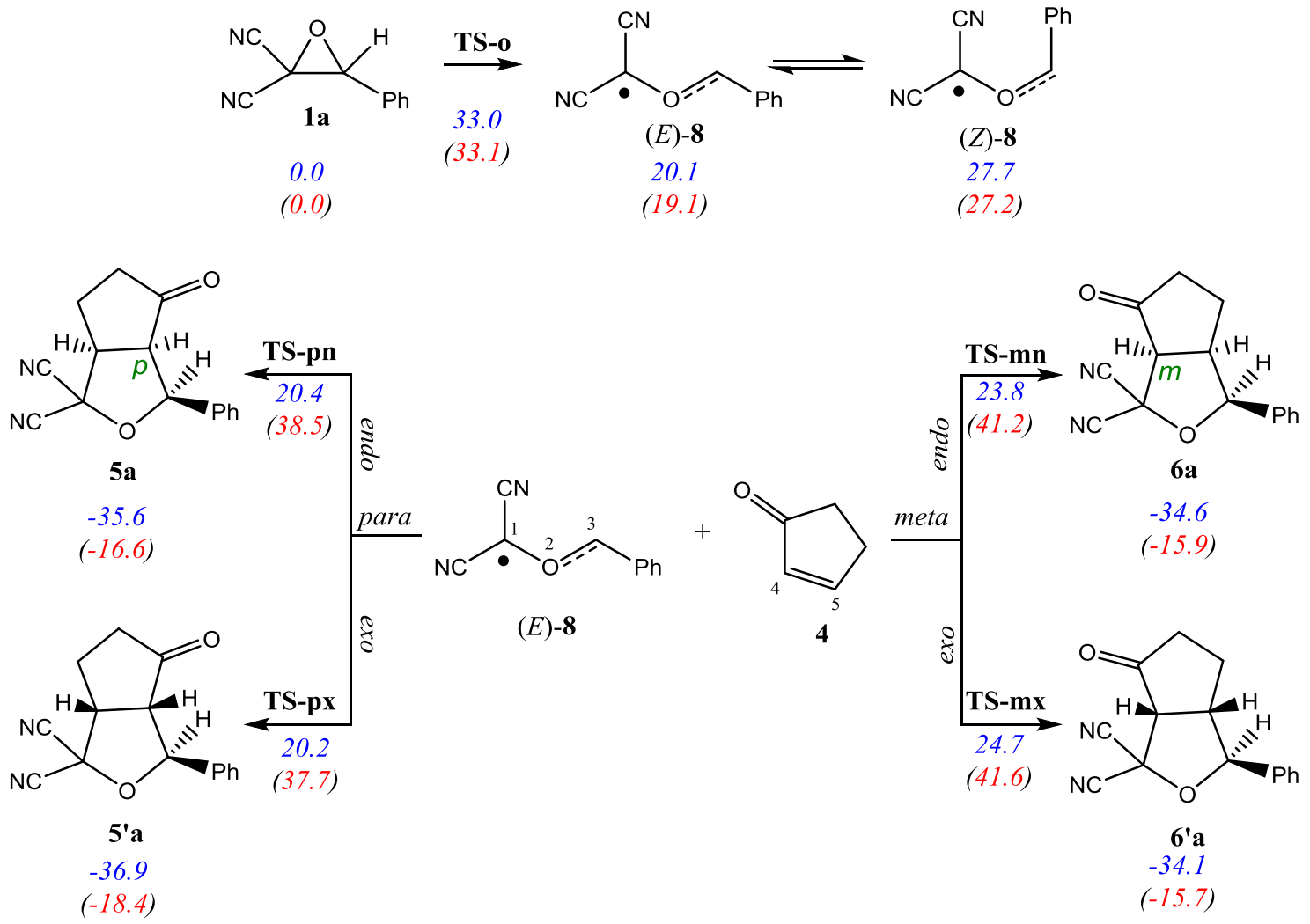

Scheme 2. Domino reaction between the oxirane 1a and 2-cyclopentenone (4). Relative enthalpies, in blue, and Gibbs free energies, in red, are given in $\mathrm{kcal} \cdot \mathrm{mol}^{-1}$.

Due to the non-symmetry of CY 8 and 2-cyclopentenone (4), four reactive channels are feasible along the 32CA reaction between them (see Scheme 2). The two endo and exo stereoisomeric reactive channels are related to the two stereoisomeric approach modes of 2- 
cyclopentenone (4) toward the $\mathrm{sp}^{2}$ hybridized $\mathrm{O} 2$ oxygen atom of $\mathrm{CY} \mathbf{8}$, so that along the endo approach, the cyclopentenone ring is situated above the $\mathrm{O} 2$ oxygen of the $\mathrm{CY}$ framework. The two possible meta and para regioisomeric channels are related to the two regioisomeric approach modes of the $\mathrm{C} 4$ or $\mathrm{C} 5$ carbon atoms of 2-cyclopentenone (4) toward the $\mathrm{C} 1$ carbon of $\mathrm{CY} \mathbf{8}$ in such a manner that, along the meta reactive pathway associated with the $\mathrm{C} 1-\mathrm{C} 4$ bond formation, the carbonyl group of the cyclopentenone framework is situated at the third position relative to the tetrahydrofuran oxygen atom. One TS and its corresponding cycloadduct were located and characterized for each of the four competitive reaction channels, thus indicating that the 32CA reaction between CY 8 and 2-cyclopentenone (4) takes place through a one-step mechanism (see Scheme 2).

The activation enthalpies associated with the four competitive reaction channels of the 32CA reaction between CY 8 and 2-cyclopentenone (4) are 0.2 (TS-pn), 0.1 (TS-px), 3.6 (TS-mn) and $4.6($ TS- $\mathbf{m x}) \mathrm{kcal} \cdot \mathrm{mol}^{-1}$, formation of the corresponding tetrahydrofurans being strongly exothermic by between 54 and $57 \mathrm{kcal} \cdot \mathrm{mol}^{-1}$. Two appealing conclusions can be drawn from these energy results: i) the 32CA reaction between CY 8 and 2-cyclopentenone (4) takes place with a very low activation enthalpy, 0.1 (TS-px) $\mathrm{kcal} \cdot \mathrm{mol}^{-1}$; ii) this $32 \mathrm{CA}$ reaction is completely para regioselective, as TS-mn is $3.5 \mathrm{kcal} \cdot \mathrm{mol}^{-1}$ higher in energy than the most favorable TS-px, and presents poor exo stereoselectivity, as TS-pn is only 0.1 $\mathrm{kcal} \cdot \mathrm{mol}^{-1}$ higher in energy than TS-px. These results are in reasonable agreement with the experimental outcomes in which a mixture of para endo/exo adducts is obtained in a 59:41 ratio.

Figure 2 shows the enthalpy and Gibbs free energy profiles associated with the domino reaction between the oxirane 1a and 2-cyclopentenone (4) in toluene. Along the ring opening of the oxirane 1a, the relative Gibbs free energies are slightly higher than the enthalpy ones as a consequence of the unimolecular character of the reaction. Thus, while the activation Gibbs 
free energy increases only by $0.1 \mathrm{kcal} \cdot \mathrm{mol}^{-1}$, the endergonic character of the reaction decreases by $1.1 \mathrm{kcal} \cdot \mathrm{mol}^{-1}$ due to the slightly favorable relative entropy associated with the formation of CY 8 (see Table S3 of the Supplementary data). However, along the 32CA reaction, the relative Gibbs free energies considerably increase as a consequence of the unfavorable entropies associated with this bimolecular process. Thus, while the activation Gibbs free energies associated with the $32 \mathrm{CA}$ reaction increase by $17-18 \mathrm{kcal} \cdot \mathrm{mol}^{-1}$, the exergonic character of the reaction decreases by ca. $19 \mathrm{kcal} \cdot \mathrm{mol}^{-1}$.

Figure 2. Enthalpy, in blue, and Gibbs free energy, in red, profiles (in $\mathrm{kcal} \cdot \mathrm{mol}^{-1}$ ) associated with the domino reaction between the oxirane 1a and 2-cyclopentenone (4) in toluene. Relative energies are given with respect to $\mathbf{1 a}+\mathbf{4}$.

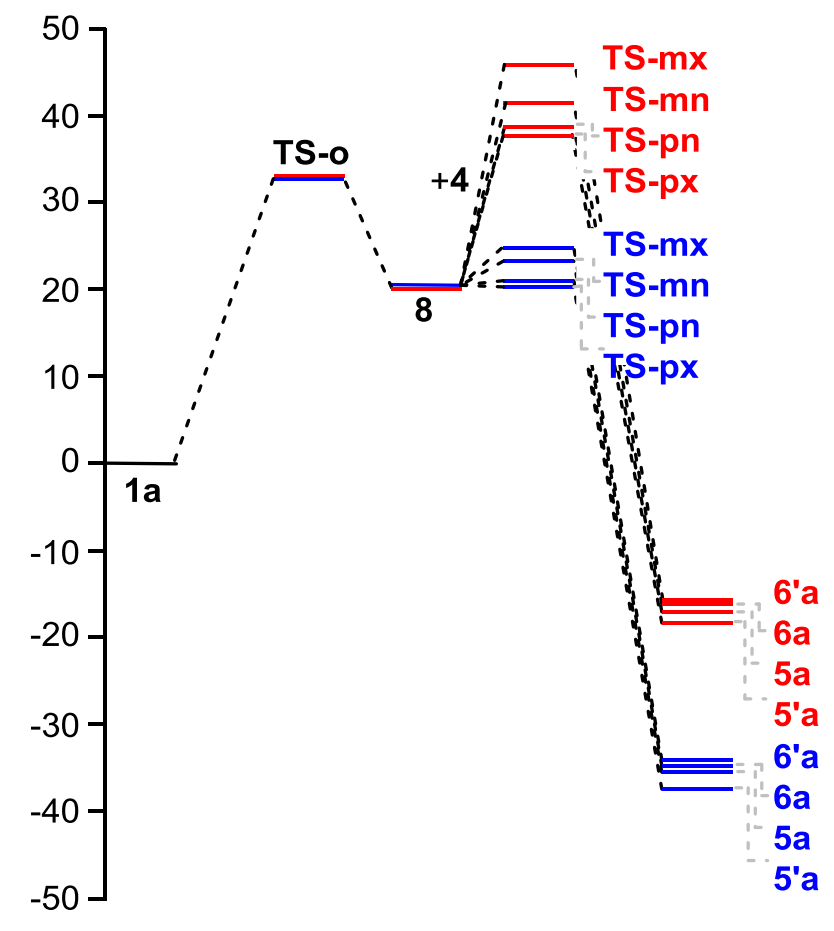

Some appealing conclusions can be drawn from these thermodynamic profiles: i) despite the very low activation enthalpy associated with the $32 \mathrm{CA}$ reaction, the endergonic character of the formation of CY 8 together with the unfavorable activation entropies associated with the 32CA reaction with 2-cyclopentenone (4) causes this reaction to be the rate-determining step of this domino process. The high activation Gibbs free energy associated with the rate- 
determining step, $37.7 \mathrm{kcal} \cdot \mathrm{mol}^{-1}$, accounts for the hard thermal conditions required for obtaining the tetrahydrofurans $\mathbf{5 ( ' ) a}$ and $\mathbf{6}(') \mathbf{a}$; ii) as the Gibbs free energy difference between TS-px and TS-mn is $3.5 \mathrm{kcal} \cdot \mathrm{mol}^{-1}$, this $32 \mathrm{CA}$ remains completely para regioselective, in complete agreement with the experimental outcomes; iii) inclusion of entropies to enthalpies increases the Gibbs free energy difference between TS-pn and TS-px to $0.8 \mathrm{kcal} \cdot \mathrm{mol}^{-1}$, in reasonable agreement with the experimental endo/exo ratio of $\sim 60 / 40$; and iv) finally, the high activation Gibbs free energy associated with the retro-32CA reaction, ca. $54 \mathrm{kcal} \cdot \mathrm{mol}^{-1}$, makes this domino reaction irreversible. Consequently, the observed reaction mixture of the tetrahydrofurans endo 5a and exo 5'a is obtained by kinetic control. In addition, the high exergonic character of this process makes this domino reaction thermodynamically very favorable.

The geometries of the TSs involved in the domino reaction between the oxirane 1a and 2cyclopentenone (4) in toluene are given in Figure 3. At TS-o, involved in the thermal ring opening of the oxirane 1a, the distance between the two $\mathrm{C} 1$ and $\mathrm{C} 3$ carbons is $2.090 \AA$. At the para TSs, the distances between the $\mathrm{C} 1$ and $\mathrm{C} 5$, and the $\mathrm{C} 3$ and $\mathrm{C} 4$ carbons involved in the single bond formation are 2.363 and $2.391 \AA$ at TS-pn, and 2.457 and $2.293 \AA$ at TS-px, respectively. Likewise, at the meta TSs, the distances between the $\mathrm{C} 1$ and $\mathrm{C} 4$, and the $\mathrm{C} 3$ and C5 carbons involved in the single bond formation are 2.528 and $2.239 \AA$ at TS-mn, and 2.503 and 2.245 $\AA$ at TS-mx, respectively. Three interesting conclusions can be drawn from these geometrical parameters: i) along the most favorable para regioisomeric reactive channels, while the $\mathrm{C}-\mathrm{C}$ bond formation at the most favorable TS-px seems to be slightly asynchronous $(\Delta \mathrm{l}=0.16)$, at TS-pn it appears to be practically synchronous $(\Delta \mathrm{l}=0.03)$; ii) at the most favorable TS-px, the $\mathrm{C}-\mathrm{C}$ bond formation involving the $\mathrm{C} 1$ pseudoradical carbon of $\mathrm{CY} \mathbf{8}$ appears to be less advanced than that involving the $\mathrm{C} 3$ carbon; iii) in general, the most unfavorable meta TSs are slightly more asynchronous than the para ones (see Figure 3). 
Figure 3. MPWB1K/6-311G(d) geometries of the TSs involved in the domino reaction between the oxirane 1a and 2-cyclopentenone (4) in toluene; the distances between the carbons involved in the bond breaking and bond formation, as well as the asynchronicity $\Delta \mathrm{l}$, are given in angstroms, $\AA$.
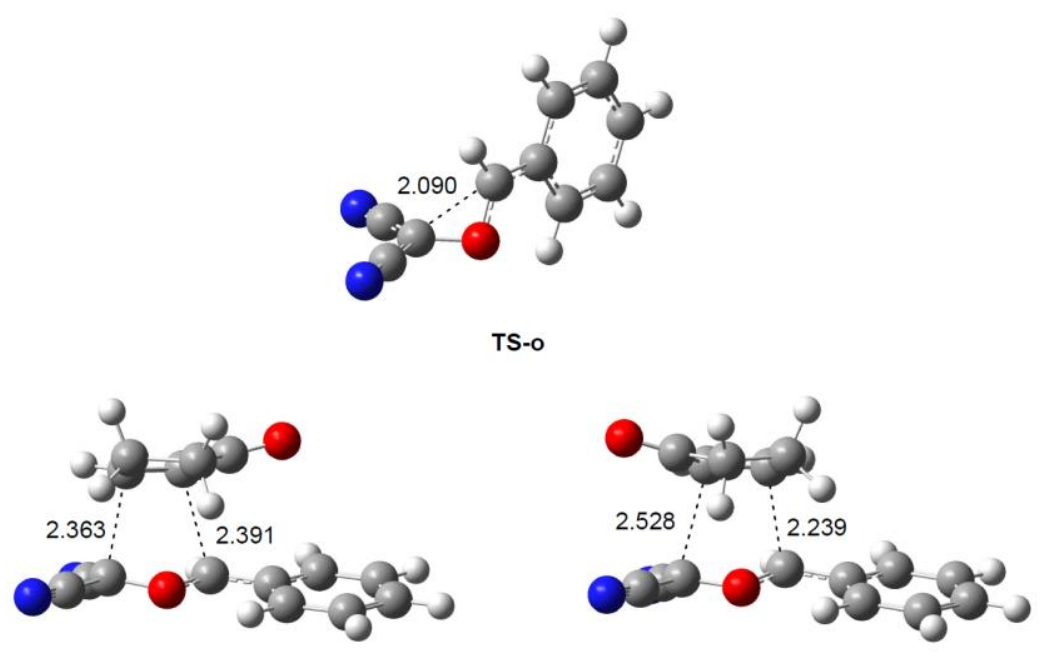

TS-pn

TS-mn

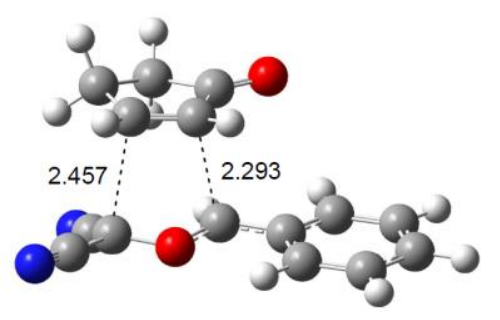

TS-px

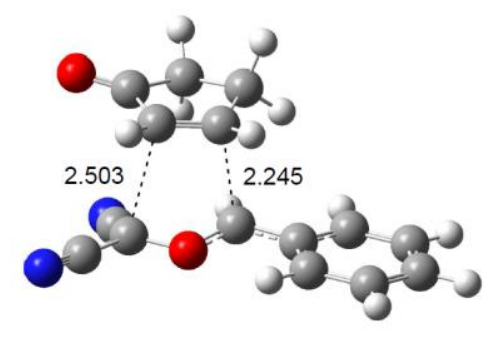

TS-mx

Finally, the electronic nature of the 32CA reaction between CY 8 and 2-cyclopentenone (4) was evaluated by computing the Global Electron Density Transfer ${ }^{22}$ (GEDT) at the TSs associated with the four reactive pathways in toluene. Along a polar reaction, there is an electron density transfer from the nucleophile to the electrophile, which is measured by the GEDT value at the TSs of the reactions; the larger the GEDT at the TS, the more polar the reaction is. Cycloadditions with GEDT values near 0.0e correspond to non-polar processes, whereas values higher than $0.2 \mathrm{e}$ correspond to polar processes. Interestingly, thorough studies have permitted to establish good correlations between the polar character of the reactions and their feasibility; the more polar the reaction character, the faster the reaction is. It is 
noteworthy that the GEDT ${ }^{22}$ concept comes from the observation that the electron density transfer that takes place from a nucleophile to an electrophile along a polar reaction is not a local process, but a global one involving the two molecules.

The negligible values of GEDT computed at the cyclopentenone framework of the TSs, -0.02e (TS-pn), 0.01e (TS-px), 0.02e (TS-mn) and 0.01e (TS-mx), emphasize the non-polar character of this $32 \mathrm{CA}$ reaction, despite the strong electrophilic character of CY $8, \omega=4.29$ $\mathrm{eV}^{23}$ and the moderate nucleophilic character of 2-cyclopentenone (4), $N=2.66 \mathrm{eV}{ }^{24}$ The relatively low activation energy associated with this $32 \mathrm{CA}$ reaction, together with the nonpolar character of the reaction, and the topological analysis of the ELF of CY 8, which shows a pseudoradical structure (see Supplementary data), is in agreement with a pmr-type of 32CA reaction. $^{19 b}$

\subsubsection{Bonding evolution theory study of the molecular mechanism of the 32CA} reaction between CY 8 and 2-cyclopentenone (4)

When trying to achieve a better understanding of bonding changes in organic reactions, the so-called bonding evolution theory ${ }^{21}$ has proven to be a very useful methodological tool. This quantum-chemical methodology makes it possible to understand the bonding changes along a reaction path and, thus, to establish the nature of the electronic rearrangement associated with a given molecular mechanism. ${ }^{25}$ Consequently, in order to establish the molecular mechanism of the 32CA reaction between CY 8 and 2-cyclopentenone (4), such a study of the bonding changes along the most favorable paralexo reactive channel was performed (the complete study is provided in the Supplementary data).

Some appealing conclusions can be drawn from this bonding evolution theory study: i) the nine phases in which the para/exo reactive channel is divided allows the non-concerted nature of the reaction to be established, and consequently the pericyclic mechanism proposed for 
these $32 \mathrm{CA}$ reactions to be ruled out; ${ }^{26}$ ii) formation of the first $\mathrm{C} 1-\mathrm{C} 5$ single bond takes place at a $\mathrm{C}-\mathrm{C}$ distance of $2.20 \AA$ by the $\mathrm{C}$-to-C coupling of the two $\mathrm{C} 1$ and $\mathrm{C} 5$ pseudoradical centers with an initial population of $1.17 \mathrm{e}$, the former making a considerably larger contribution to the $\mathrm{C} 1-\mathrm{C} 5$ bond formation; ${ }^{22}$ iii) formation of the second $\mathrm{C} 3-\mathrm{C} 4$ single bond takes place at a $\mathrm{C}-\mathrm{C}$ distance of $1.97 \AA$ by a C-to- $\mathrm{C}$ coupling of the two pseudoradical centers previously generated at the $\mathrm{C} 3$ and $\mathrm{C} 4$ carbons with an initial population of $1.25 \mathrm{e}^{.22}$ iv) formation of the two $\mathrm{C}-\mathrm{C}$ single bonds is slightly asynchronous; v) the topology of the ELF of TS-px reveals an inverse asynchronicity to that suggested by the geometrical analysis (see Figure 3): formation of the $\mathrm{C} 1-\mathrm{C} 5$ bond involving the pseudoradical $\mathrm{C} 1$ carbon already present in $\mathrm{CY} 8$ is more advanced than the $\mathrm{C} 3-\mathrm{C} 4$ one; vi) the low activation energy associated to TS-px can be mainly related with the depopulation of the $\mathrm{O} 2-\mathrm{C} 3$ single bond of CY 8 and the C4-C5 double bond of cyclopentenone (4). These behaviors, together with the fact that the activation energy relative to $\mathbf{M C}-\mathbf{p x}$ is $6.3 \mathrm{kcal} \cdot \mathrm{mol}^{-1}$, permit to classify this $32 \mathrm{CA}$ reaction as a pmr-type one, in clear agreement with the pseudoradical electronic structure of CY 8 (see Table S1 in Supplementary data). ${ }^{19 b}$ Consequently, the presence of the phenyl substituent at the $\mathrm{C} 3$ carbon of $\mathrm{CY} \mathbf{8}$ changes the parent $p d r$-type reactivity to a pmrtype one; vii) in this non-polar 32CA reaction, the formation of the $\mathrm{C} 4$ pseudoradical center at the $\alpha$ position of the carbonyl group appears to be favored over that at the $\beta$ one due to the electron-withdrawing character of the carbonyl group. This behavior accounts for the regioselectivity experimentally observed in this non-polar reaction.

\subsection{Biological evaluation}

Because tetrahydrofuran-containing scaffolds can exhibit bioactivities, some of the synthesized derivatives were evaluated. The compounds $\mathbf{3 b a}, \mathbf{3 b c}, \mathbf{5 a}$ and 5'c were assessed for their antibacterial activities against several bacterial species representative of those most 
frequently encountered at the Hospital and responsible of healthcare-associated infections (HAI): Escherichia coli, Klebsiella pneumoniae, Enterobacter cloacae, Acinetobacter baumannii, Pseudomonas aeruginosa, Staphylococcus aureus and Enterococcus faecalis. Bacteria were treated with different concentrations of compounds (range 1 to $64 \mu \mathrm{g} . \mathrm{mL}^{-1}$ ). For most of the bacteria tested, both Gram-positive and Gram-negative, we were able to determine antibacterial activities (i.e. determination of the Minimum Inhibitory Concentration, Table 4). Even if we observed globally a weak antibacterial activity for these compounds, most of them inhibit bacterial growth (PI = percentage of inhibition). Of particular interest, the cycloadduct 5'c showed higher antibacterial activities, with MICs of 32 and $16 \mu \mathrm{g} . \mathrm{mL}^{-1}$ against $S$. aureus and E. faecalis, respectively.

Table 4. Antibacterial activity MICs $\left(\mu \mathrm{g} \cdot \mathrm{mL}^{-1}\right)$ of the compounds $\mathbf{3 b a}, \mathbf{3 b c}, \mathbf{5 a}, \mathbf{5}$ 'c and ATB (reference antibiotic) obtained by broth microdilution method, according to CLSI guidelines $\left(\mathrm{n}=2\right.$, see Supplementary data), and/or PI\% (percentage of inhibition) at $64 \mu \mathrm{g} \cdot \mathrm{mL}^{-1}$.

\begin{tabular}{lccccc}
\hline Bacteria & 3ba & 3bc & 5a & 5'c & ATB \\
\hline Escherichia coli & NI & NI & NI & NI & $4^{a}$ \\
ABC 5 & $>64$ & $>64$ & $>64$ & $>64$ & $2^{b}$ \\
Klebsiella pneumoniae & $29 \%$ & $45 \%$ & & $42 \%$ & \\
ABC 12 & $>64$ & $>64$ & $>64$ & $>64$ & $2^{b}$ \\
\hline Enterobacter cloacae & $50 \%$ & $56 \%$ & $50 \%$ & $63 \%$ & \\
ABC 291 & $>64$ & $>64$ & $>64$ & $>64$ & $8^{c}$ \\
\hline Acinetobacter baumannii & $45 \%$ & $39 \%$ & $55 \%$ & $52 \%$ & \\
ABC 14 & $>64$ & $>64$ & $>64$ & $>64$ & \multirow{2}{*}{$8^{c}$} \\
Pseudomonas aeruginosa & $58 \%$ & $59 \%$ & $62 \%$ & $55 \%$ & \\
ABC 4 & $>64$ & $>64$ & $>64$ & $\mathbf{3 2}$ & $<1^{d}$ \\
Staphylococcus aureus & $28 \%$ & $31 \%$ & $38 \%$ & & \\
ABC 1 & $>64$ & $>64$ & $>64$ & $\mathbf{1 6}$ & $2^{e}$ \\
\hline Enterococcus faecalis & $78 \%$ & $89 \%$ & $78 \%$ & & \\
ABC 3 & & & & &
\end{tabular}

NI: not interpretable. ${ }^{a}$ Amoxicillin. ${ }^{b}$ Amikacin.

${ }^{c}$ Ticarcillin. ${ }^{d}$ Penicillin G. ${ }^{e}$ Vancomycin.

These compounds were also assessed for their antiproliferative activities on both HeLa (Table 5) and L132 (Table 6) cell lines. Indeed, HeLa (an adenocarcinoma cell line from cervix) and L132 (an epithelial cell line originally thought to be derived from embryonic lung 
tissue) are currently used as models for antiproliferative assays. Cells were treated with three concentrations of compounds $(100,50$ and $10 \mu \mathrm{M})$. The discrimination was done at $100 \mu \mathrm{M}$. After $48 \mathrm{~h}$ treatment, $\mathbf{3} \mathbf{b a}$ and $\mathbf{3 b c}$ were found of interest. In fact, growth of HeLa and L-132 cells was inhibited by $\mathbf{3 b a}$ and $\mathbf{3 b c}$, respectively (Table 5 and Table 6), with a very interesting antiproliferative activity of $\mathbf{3 b c}$ on L132, even at $10 \mu \mathrm{M}$.

Table 5. Antiproliferative activity of the compounds 3ba, 3bc, 5a and 5'c on HeLa cell line (results are expressed as a percentage of survival determined by the MTT assay after $48 \mathrm{~h}$ of treatment at three different concentrations; results are mean \pm SEM of two independent experiments).

\begin{tabular}{ccccc}
\hline Compound & 3ba & 3bc & 5a & 5'c \\
\hline $100 \mu \mathrm{M}$ & 0.53 & 57.90 & 89.71 & 95.58 \\
$50 \mu \mathrm{M}$ & $0.73 \pm 0.17$ & $82.84 \pm 21.10$ & $92.71 \pm 5.78$ & $103.12 \pm 9.25$ \\
\hline $10 \mu \mathrm{M}$ & $30.42 \pm 1.57$ & $98.37 \pm 9.53$ & $106.13 \pm 6.00$ & $104.72 \pm 2.75$ \\
\hline
\end{tabular}

Table 6. Antiproliferative activity of the compounds $\mathbf{3 b a}, \mathbf{3 b c}, \mathbf{5 a}$ and $\mathbf{5}$ 'c on L132 cell line (results are expressed as a percentage of survival determined by the MTT assay after $48 \mathrm{~h}$ of treatment at three different concentrations; results are mean \pm SEM of two independent experiments; ND: not determined).

\begin{tabular}{ccccc}
\hline Compound & 3ba & 3bc & 5a & 5'c \\
\hline $100 \mu \mathrm{M}$ & 0.27 & 19.53 & 85.36 & 87.66 \\
\hline $50 \mu \mathrm{M}$ & $16.03 \pm 3.29$ & $17.20 \pm 9.99$ & ND & ND \\
\hline $10 \mu \mathrm{M}$ & $64.27 \pm 5.50$ & $19.94 \pm 15.02$ & ND & ND \\
\hline
\end{tabular}

In order to study the mode of action of the compounds, we evaluated their bioactivity against a short panel of disease-related kinases: CDK2/Cyclin A; CDK5/p25; CDK9/Cyclin T; PIM1; GSK-3; RIPK3; Haspin; Aurora B. Among these selected targets, some are notably involved in cellular growth (including the control of the cell-division cycle for the human CDK2/Cyclin A). This class of enzymes should be putative targets of antiproliferative compounds described here (e.g. 5a). The compounds were tested at $10 \mu \mathrm{M}$ final concentration (15 $\mu \mathrm{M} \mathrm{ATP)} \mathrm{and} \mathrm{none} \mathrm{of} \mathrm{the} \mathrm{derivatives} \mathrm{was} \mathrm{shown} \mathrm{to} \mathrm{inhibit} \mathrm{significantly} \mathrm{the} \mathrm{enzymatic}$ activities tested (data not shown). 


\section{Conclusions}

Thus, different polysubstituted tetrahydrofurans were synthesized by reacting 2,2-dicyano3-aryloxiranes with either enones, such as chalcones and 2-cyclopentenone, or enamines, here 2-morpholinoacrylonitrile. We showed, by using chalcones as enones, that microwaves can be efficiently used to shorten the reaction times and enhance the diastereoselectivities.

Importantly, the molecular mechanism of the reaction between the oxirane 1a and 2cyclopentenone (4), yielding the tetrahydrofurans 5(')a and 6(')a, was theoretically studied using DFT methods. The reaction is a domino process that comprises two sequential reactions: (i) the thermal ring opening of the oxirane 1a to yield $\mathrm{CY} \mathbf{8}$ and (ii) its $32 \mathrm{CA}$ reaction with 2-cyclopentenone (4) to give the tetrahydrofurans $\mathbf{5 ( ' ) a}$ and 6(')a. The endergonic character of the formation of CY 8 together with the unfavorable activation entropies associated with the 32CA reaction with 2-cyclopentenone (4) causes this reaction to be the rate-determining step of this domino process.

The 32CA reaction between CY 8 and 2-cyclopentenone (4) takes place with a very low activation enthalpy, $0.1 \mathrm{kcal} \cdot \mathrm{mol}^{-1}$. This $32 \mathrm{CA}$ reaction is completely para regioselective, and presents poor exo stereoselectivity, in reasonable agreement with the experimental outcome. The negligible GEDT values computed at the TSs emphasize the non-polar character of this 32CA reaction.

The bonding evolution theory study of the most favorable para/exo reactive channel shows the non-concerted nature of the mechanism. ELF analysis of CY 8 indicates that this threeatom-component has a pseudoradical structure participating in a pmr-type 32CA reaction towards 2-cyclopentenone (4). In this asynchronous process, the formation of the $\mathrm{C} 1-\mathrm{C} 5$ single bond takes place before the formation of the $\mathrm{C} 3-\mathrm{C} 4$ one, in disagreement with the asynchronicity showed by the lengths of the two $\mathrm{C}-\mathrm{C}$ forming bonds at the corresponding TS. 
The formation of the $\mathrm{C} 1[3]-\mathrm{C} 5[4]$ single bonds takes place at $\mathrm{C}-\mathrm{C}$ distances of $2.20[1.97]$ by a C-to-C coupling of the two $\mathrm{C} 1[3]$ and $\mathrm{C} 5[4]$ pseudoradical centers. The high electron density of the $\mathrm{C} 1$ pseudoradical center of CY $\mathbf{8}$ demands the asymmetric depopulation of the C4-C5 bonding region of 2-cyclopentenone (4), in which the formation of the $\mathrm{C} 4$ pseudoradical center at the $\alpha$ position appears to be favored over that at the $\beta$ one due to the presence of the electron-withdrawing carbonyl group. This behavior accounts for the regioselectivity experimentally observed in this non-polar reaction.

\section{Experimental}

\subsection{General}

Column chromatography separations were achieved on silica gel (40-63 $\mu \mathrm{m})$. Melting points were measured on a Kofler apparatus. ${ }^{1} \mathrm{H}$ and ${ }^{13} \mathrm{C}$ Nuclear Magnetic Resonance (NMR) spectra were recorded with a Bruker ARX $200 \mathrm{P}$ or a Bruker AC $300 \mathrm{P}$ spectrometer $\left({ }^{1} \mathrm{H}\right.$ at 200 or $300 \mathrm{MHz}$, respectively, and ${ }^{13} \mathrm{C}$ at 50 or $75 \mathrm{MHz}$, respectively). ${ }^{1} \mathrm{H}$ chemical shifts $(\delta)$ are given in ppm relative to the solvent residual peak, ${ }^{13} \mathrm{C}$ chemical shifts are relative to the central peak of the solvent signal. ${ }^{27}$ Mass spectra (HRMS) measurements were performed at the CRMPO (Centre Régional de Mesures Physiques de l'Ouest) of Rennes by using a a Varian MAT 311 spectrometer in positive electrospray CI mode.

\subsubsection{Starting materials}

The oxiranes $\mathbf{1}^{6 \mathrm{~b}}$ and 2-morpholinoacrylonitrile $(\mathbf{9})^{28}$ were prepared according to a described procedure. Toluene was distilled before use. Reactions were performed under dry argon. Petrol refers to petroleum ether (bp $40-60^{\circ} \mathrm{C}$ ).

\subsubsection{Crystallography}

The samples were studied with graphite monochromatized Mo-K $\alpha$ radiation $(\lambda=0.71073$ Å). X-ray diffraction data were collected at $T=100(2) \mathrm{K}$ using APEXII Bruker-AXS 
diffractometer. The structure was solved by direct methods using the SIR97 program, ${ }^{29}$ and then refined with full-matrix least-square methods based on $F^{2}\left(\right.$ SHELX-97) ${ }^{30}$ with the aid of the WINGX program. ${ }^{31}$ All non-hydrogen atoms were refined with anisotropic thermal parameters. $\mathrm{H}$ atoms were finally included in their calculated positions. Molecular diagrams were generated by ORTEP-3 (version 2.02). ${ }^{31}$

\subsection{General procedures:}

General procedure 1: A mixture of epoxide $(2.0 \mathrm{mmol})$ and enone $(2.0 \mathrm{mmol})$ in dry toluene $(30 \mathrm{~mL})$ was heated at reflux under $\mathrm{N}_{2}$. The mixture was then evaporated to dryness and the residue was purified as specified in the product description.

General procedure 2: A mixture of epoxide $(2.0 \mathrm{mmol})$ and enone $(2.0 \mathrm{mmol})$ was heated in a microwave oven (power, temperature and time are given in the product description). The residue was purified as specified in the product description.

General procedure 3: A mixture of epoxide $(2.0 \mathrm{mmol})$, enone $(2.0 \mathrm{mmol})$ and $\mathrm{CuCl}(0.6$ mmol) in dry toluene $(30 \mathrm{~mL})$ was heated at reflux under $\mathrm{N}_{2}$. The mixture was then evaporated to dryness and the residue was purified as specified in the product description.

General procedure 4: A mixture of epoxide $(2.0 \mathrm{mmol})$ and 2-morpholinoacrylonitrile $(9$, $2.0 \mathrm{mmol})$ in dry toluene $(30 \mathrm{~mL})$ was heated at reflux under $\mathrm{N}_{2}$. The mixture was then evaporated to dryness and the residue was purified as specified in the product description.

\subsection{Diastereoisomers of 4-benzoyl-5-(4-chlorophenyl)-3-phenyltetrahydrofuran-2,2-}

dicarbonitrile. The general procedure 1 (reflux of $56 \mathrm{~h}$ ), using 3-(4-chlorophenyl)oxirane2,2-dicarbonitrile (1b, $0.41 \mathrm{~g})$ and chalcone (2a, $0.42 \mathrm{~g}$ ), gave a 52/48 mixture from which the predominant diastereoisomer 3ba was isolated by chromatography over silica gel (eluent: petrol/AcOEt 90:10) in $42 \%$ yield as a white powder: $\mathrm{mp} 182{ }^{\circ} \mathrm{C} ;{ }^{1} \mathrm{H} \mathrm{NMR}\left(\mathrm{CDCl}_{3}\right) \delta 4.89$ (d, $1 \mathrm{H}, J=11.5 \mathrm{~Hz}, \mathrm{H} 3), 5.13(\mathrm{t}, 1 \mathrm{H}, J=10.6 \mathrm{~Hz}, \mathrm{H} 4), 5.95$ (d, 1H, $J=9.6 \mathrm{~Hz}, \mathrm{H} 5), 6.92-6.96$ $(\mathrm{m}, 2 \mathrm{H}), 7.11-7.16(\mathrm{~m}, 2 \mathrm{H}), 7.41-7.59(\mathrm{~m}, 8 \mathrm{H}), 7.68-7.72(\mathrm{~m}, 2 \mathrm{H}) ;{ }^{13} \mathrm{C} \mathrm{NMR}\left(\mathrm{CDCl}_{3}\right) \delta 53.2$ 
$(\mathrm{CH}), 56.5(\mathrm{CH}), 73.4(\mathrm{C}), 83.7(\mathrm{CH}), 112.3(\mathrm{CN}), 112.8(\mathrm{CN}), 128.4(2 \mathrm{CH}), 128.4(2 \mathrm{CH})$, $128.5(2 \mathrm{CH}), 128.7(2 \mathrm{CH}), 129.2(2 \mathrm{CH}), 129.7(2 \mathrm{CH}), 129.8(\mathrm{C}), 130.1(\mathrm{CH}), 133.3(\mathrm{C})$, $134.5(\mathrm{CH}), 135.4(\mathrm{C}), 136.3(\mathrm{C}), 192.6(\mathrm{C}=\mathrm{O})$; HRMS, m/z: 272.0931 found (calcd for $\mathrm{C}_{18} \mathrm{H}_{12} \mathrm{~N}_{2} \mathrm{O},\left[\mathrm{M}-\mathrm{ClC}_{6} \mathrm{H}_{4} \mathrm{CHO}\right]^{+\bullet}$ requires: 272.0950). The general procedure $2(120 \mathrm{~W}, 6 \mathrm{~min}$ to reach $80^{\circ} \mathrm{C}, 9 \mathrm{~min}$ to reach $120^{\circ} \mathrm{C}$, and $40 \mathrm{~min}$ at $120^{\circ} \mathrm{C}$ ), using 3-(4-chlorophenyl)oxirane2,2-dicarbonitrile (1b, $0.41 \mathrm{~g})$ and chalcone (2a, $0.42 \mathrm{~g}$ ), gave a 65/35 mixture from which the preponderant diastereoisomer 3ba was isolated by chromatography over silica gel (eluent: petrol/AcOEt 90:10) in 51\% yield. The general procedure 3 (reflux of $22 \mathrm{~h}$ ), using 3-(4chlorophenyl)oxirane-2,2-dicarbonitrile (1b, $0.41 \mathrm{~g})$ and chalcone (2a, 0.42 g), gave a 65/35 mixture from which the preponderant diastereoisomer 3ba was isolated by chromatography over silica gel (eluent: petrol/AcOEt 90:10) in 50\% yield. The minor diastereoisomer 3'ba was identified by selected NMR data: ${ }^{1} \mathrm{H}$ NMR $\left(\mathrm{CDCl}_{3}\right) \delta 4.05(\mathrm{t}, 1 \mathrm{H}, J=10.5 \mathrm{~Hz}, \mathrm{H} 4), 5.39$ $(\mathrm{d}, 1 \mathrm{H}, J=10.3 \mathrm{~Hz})$.

\subsection{Diastereoisomers of 4-benzoyl-3,5-diphenyltetrahydrofuran-2,2-dicarbonitrile.}

The general procedure 1 (reflux of $62 \mathrm{~h}$ ), using 3-phenyloxirane-2,2-dicarbonitrile (1a, 0.34 g) and chalcone (2a, 0.42 g), gave a 51/49 mixture from which the preponderant diastereoisomer 3aa was isolated by chromatography over silica gel (eluent: petrol/AcOEt 90:10) in $31 \%$ yield as a beige powder: $\mathrm{mp} 138-139{ }^{\circ} \mathrm{C} ;{ }^{1} \mathrm{H} \mathrm{NMR}\left(\mathrm{CDCl}_{3}\right) \delta 4.93(\mathrm{~d}, 1 \mathrm{H}, J=$ $11.6 \mathrm{~Hz}, \mathrm{H} 3), 5.13$ (dd, 1H, $J=11.6$ and $9.6 \mathrm{~Hz}, \mathrm{H} 4), 5.99(\mathrm{~d}, 1 \mathrm{H}, J=9.5 \mathrm{~Hz}, \mathrm{H} 5), 6.98-7.02$ $(\mathrm{m}, 2 \mathrm{H}), 7.14-7.27(\mathrm{~m}, 4 \mathrm{H}), 7.41-7.44(\mathrm{~m}, 4 \mathrm{H}), 7.50-7.56(\mathrm{~m}, 3 \mathrm{H}), 7.66-7.70(\mathrm{~m}, 2 \mathrm{H}) ;{ }^{13} \mathrm{C}$ NMR $\left(\mathrm{CDCl}_{3}\right) \delta 53.3(\mathrm{CH}), 56.5(\mathrm{CH}), 73.4(\mathrm{C}), 84.5(\mathrm{CH}), 112.4(\mathrm{CN}), 113.0(\mathrm{CN}), 127.1$ $(2 \mathrm{CH}), 128.4(2 \mathrm{CH}), 128.5(4 \mathrm{CH}), 130.0(2 \mathrm{CH}), 129.6(2 \mathrm{CH}), 129.4(\mathrm{CH}), 130.0(\mathrm{CH}), 130.1$ (C), $134.2(\mathrm{CH}), 134.8(\mathrm{C}), 136.5(\mathrm{C}), 192.7(\mathrm{C}=\mathrm{O})$; HRMS, $m / z: 378.1400$ found (calcd for $\mathrm{C}_{25} \mathrm{H}_{18} \mathrm{~N}_{2} \mathrm{O}_{2}, \mathrm{M}^{+\bullet}$ requires: 378.1368$)$. The general procedure $2\left(120 \mathrm{~W}, 6\right.$ min to reach $80^{\circ} \mathrm{C}$, 9 min to reach $120^{\circ} \mathrm{C}$, and $40 \mathrm{~min}$ at $120^{\circ} \mathrm{C}$ ), using 3-phenyloxirane-2,2-dicarbonitrile (1a, 
$0.34 \mathrm{~g}$ ) and chalcone (2a, $0.42 \mathrm{~g}$ ), gave a 68/32 mixture from which the preponderant diastereoisomer 3aa was isolated by chromatography over silica gel (eluent: petrol/AcOEt 90:10) in 45\% yield. The minor diastereoisomer 3'aa was identified by selected NMR data: ${ }^{1} \mathrm{H} \mathrm{NMR}\left(\mathrm{CDCl}_{3}\right) \delta 4.13(\mathrm{t}, 1 \mathrm{H}, J=10.5 \mathrm{~Hz}, \mathrm{H} 4), 4.99(\mathrm{~d}, 1 \mathrm{H}, J=10.6 \mathrm{~Hz}), 5.48(\mathrm{~d}, 1 \mathrm{H}, J=$ $10.4 \mathrm{~Hz}), 7.92-7.96(\mathrm{~m}, 2 \mathrm{H})$.

\subsection{Diastereoisomers of 4-benzoyl-5-(4-methoxyphenyl)-3-phenyltetrahydrofuran-2,2-}

dicarbonitrile. The general procedure 1 (reflux of $48 \mathrm{~h}$ ), using 3-(4-methoxyphenyl)oxirane2,2-dicarbonitrile (1c, $0.40 \mathrm{~g}$ ) and chalcone (2a, $0.42 \mathrm{~g}$ ), gave a 57/43 mixture from which the preponderant diastereoisomer 3ca was isolated by chromatography over silica gel (eluent: petrol/AcOEt 90:10) in 50\% yield as a white powder: mp $204{ }^{\circ} \mathrm{C} ;{ }^{1} \mathrm{H} \mathrm{NMR}\left(\mathrm{CDCl}_{3}\right) \delta 3.80(\mathrm{~s}$, 3H, OMe), 4.77-4.90 (m, 2H, H3, H4), 5.44 (d, 1H, J = 8.9 Hz, H5), 6.86-6.90 (m, 2H), 7.24$7.45(\mathrm{~m}, 10 \mathrm{H}), 7.49-7.53(\mathrm{~m}, 2 \mathrm{H}) ;{ }^{13} \mathrm{C} \mathrm{NMR}\left(\mathrm{CDCl}_{3}\right) \delta 55.5(\mathrm{OMe}), 56.9(\mathrm{CH}), 60.5(\mathrm{CH})$, $73.3(\mathrm{C}), 88.9(\mathrm{CH}), 112.9(\mathrm{CN}), 113.5(\mathrm{CN}), 114.7(2 \mathrm{CH}), 127.9(2 \mathrm{CH}), 128.3(2 \mathrm{CH}), 128.1$ (C), $128.7(2 \mathrm{CH}), 128.9(2 \mathrm{CH}), 129.6(2 \mathrm{CH}), 130.1(\mathrm{CH}), 130.1(\mathrm{C}), 134.4(\mathrm{CH}), 136.1(\mathrm{C})$, 160.7 (C), $194.8\left(\mathrm{C}=\mathrm{O}\right.$ ); HRMS, $m / z$ : 408.1491 found (calcd for $\mathrm{C}_{26} \mathrm{H}_{20} \mathrm{~N}_{2} \mathrm{O}_{3}, \mathrm{M}^{+\bullet}$ requires: 408.1474). The general procedure $2\left(120 \mathrm{~W}, 3 \mathrm{~min}\right.$ to reach $60^{\circ} \mathrm{C}, 6 \mathrm{~min}$ to reach $80^{\circ} \mathrm{C}$, and $35 \mathrm{~min}$ at $\left.80^{\circ} \mathrm{C}\right)$, using 3-(4-methoxyphenyl)oxirane-2,2-dicarbonitrile (1c, $0.40 \mathrm{~g}$ ) and chalcone (2a, $0.42 \mathrm{~g}$ ), gave a 83/17 mixture from which the preponderant diastereoisomer 3ca was isolated by chromatography over silica gel (eluent: petrol/AcOEt 90:10) in 53\% yield. The general procedure 3 (reflux of $18 \mathrm{~h}$ ), using 3-(4-methoxyphenyl)oxirane-2,2dicarbonitrile (1c, $0.40 \mathrm{~g}$ ) and chalcone (2a, $0.42 \mathrm{~g}$ ), gave a 56/44 mixture from which the preponderant diastereoisomer 3ca was isolated by chromatography over silica gel (eluent: petrol/AcOEt 90:10) in 53\% yield. Crystal data for 3'ca (CCDC 688220). $\mathrm{C}_{26} \mathrm{H}_{20} \mathrm{~N}_{2} \mathrm{O}_{3}, M=$ 408.44, triclinic, $P-1, a=8.5336(12), b=10.6411(14), c=13.899(2) \AA, \alpha=101.087(6), \beta=$ 107.846(6), $\gamma=111.557(6){ }^{\circ}, V=1049.0(3) \AA^{3}, Z=2, d=1.293 \mathrm{~g} \mathrm{~cm}^{-3}, \mu=0.085 \mathrm{~mm}^{-1} . \mathrm{A}$ 
final refinement on $F^{2}$ with 4754 unique intensities and 281 parameters converged at $\omega R\left(F^{2}\right)$ $=0.1151(R(F)=0.055)$ for 4326 observed reflections with $I>2 \sigma(I)$.

\subsection{Diastereoisomers of 4-benzoyl-3,5-di(4-chlorophenyl)tetrahydrofuran-2,2-}

dicarbonitrile. The general procedure 1 (reflux of $48 \mathrm{~h}$ ), using 3-(4-chlorophenyl)oxirane2,2-dicarbonitrile (1b, $0.41 \mathrm{~g})$ and 4-chlorochalcone (2b, $0.49 \mathrm{~g})$, gave a 62/38 mixture from which the preponderant diastereoisomer $\mathbf{3 b b}$ was isolated by chromatography over silica gel (eluent: petrol/AcOEt 80:20) in $35 \%$ yield as a white powder: $\mathrm{mp} 147{ }^{\circ} \mathrm{C} ;{ }^{1} \mathrm{H} \mathrm{NMR}\left(\mathrm{CDCl}_{3}\right) \delta$ $4.86(\mathrm{~d}, 1 \mathrm{H}, J=11.7 \mathrm{~Hz}, \mathrm{H} 3), 5.07(\mathrm{dd}, 1 \mathrm{H}, J=11.7$ and $9.7 \mathrm{~Hz}, \mathrm{H} 4), 5.96(\mathrm{~d}, 1 \mathrm{H}, J=9.7 \mathrm{~Hz}$, H5), 6.90-6.94 (m, 2H), 7.11-7.15 (m, 2H), 7.39-7.50 (m, 6H), $7.60(\mathrm{tt}, 1 \mathrm{H}, J=7.4$ and 1.2 $\mathrm{Hz})$, 7.68-7.71 (m, 2H); ${ }^{13} \mathrm{C} \mathrm{NMR}\left(\mathrm{CDCl}_{3}\right) \delta 53.3(\mathrm{CH}), 55.9(\mathrm{CH}), 73.0(\mathrm{C}), 83.7(\mathrm{CH})$, $112.1(\mathrm{CN}), 112.6(\mathrm{CN}), 128.2(\mathrm{C}), 128.4(4 \mathrm{CH}), 128.7(2 \mathrm{CH}), 129.2(2 \mathrm{CH}), 129.8(2 \mathrm{CH})$, $129.9(2 \mathrm{CH}), 133.1(\mathrm{C}), 134.6(\mathrm{CH}), 135.5(\mathrm{C}), 136.1(\mathrm{C}), 136.3(\mathrm{C}), 192.3(\mathrm{C}=\mathrm{O})$; HRMS, $m / z$ : 306.0564 found (calcd for $\mathrm{C}_{18} \mathrm{H}_{11}{ }^{35} \mathrm{ClN}_{2} \mathrm{O}$, [M-ClC $\left.{ }_{6} \mathrm{H}_{4} \mathrm{CHO}\right]^{+\bullet}$ requires: 306.0560 ). The general procedure 3 (reflux of $24 \mathrm{~h}$ ), using 3-(4-chlorophenyl)oxirane-2,2-dicarbonitrile (1b, $0.41 \mathrm{~g}$ ) and 4-chlorochalcone (2b, only $0.245 \mathrm{~g}$ ), gave a 69/31 mixture from which the preponderant diastereoisomer $\mathbf{3 b b}$ was isolated by chromatography over silica gel (eluent: petrol/AcOEt 80:20) in 43\% yield. The minor diastereoisomer 3'bb was identified by selected NMR data: ${ }^{1} \mathrm{H}$ NMR $\left(\mathrm{CDCl}_{3}\right) \delta 4.07(\mathrm{t}, 1 \mathrm{H}, J=10.5 \mathrm{~Hz}, \mathrm{H} 4), 4.99(\mathrm{~d}, 1 \mathrm{H}, J=10.6 \mathrm{~Hz}), 5.35$ $(\mathrm{d}, 1 \mathrm{H}, J=10.5 \mathrm{~Hz}), 7.89-8.01(\mathrm{~m}, 2 \mathrm{H})$.

\section{7. \\ Diastereoisomers \\ of \\ 4-benzoyl-3-(4-chlorophenyl)-5-(4-}

methoxyphenyl)tetrahydrofuran-2,2-dicarbonitrile. The general procedure 1 (reflux of 36 h), using 3-(4-methoxyphenyl)oxirane-2,2-dicarbonitrile (1c, 0.40 g) and 4-chlorochalcone (2b, 0.49 g), gave a 71/29 mixture from which the preponderant diastereoisomer 3cb was isolated by chromatography over silica gel (eluent: petrol/AcOEt 90:10) in 37\% yield as a yellow oil; ${ }^{1} \mathrm{H}$ NMR $\left(\mathrm{CDCl}_{3}\right) \delta 3.71(\mathrm{~s}, 3 \mathrm{H}), 4.89(\mathrm{~d}, 1 \mathrm{H}, J=11.8 \mathrm{~Hz}, \mathrm{H} 3), 5.02(\mathrm{dd}, 1 \mathrm{H}, J=$ 
11.8 and $9.5 \mathrm{~Hz}, \mathrm{H} 4), 5.95(\mathrm{~d}, 1 \mathrm{H}, J=9.5 \mathrm{~Hz}, \mathrm{H} 5), 6.64-6.68(\mathrm{~m}, 2 \mathrm{H}), 6.90-6.94(\mathrm{~m}, 2 \mathrm{H})$, 7.39-7.44 (m, 4H), 7.48-7.52 (m, 2H), $7.56(\mathrm{tt}, 1 \mathrm{H}, J=7.4$ and $1.3 \mathrm{~Hz}), 7.65-7.70(\mathrm{~m}, 2 \mathrm{H})$; ${ }^{13} \mathrm{C} \mathrm{NMR}\left(\mathrm{CDCl}_{3}\right) \delta 53.5(\mathrm{CH}), 55.3\left(\mathrm{CH}_{3}\right), 55.9(\mathrm{CH}), 72.9(\mathrm{C}), 83.2(\mathrm{CH}), 112.3(\mathrm{CN})$, $112.8(\mathrm{CN}), 113.9(2 \mathrm{CH}), 126.6(\mathrm{C}), 128.4(2 \mathrm{CH}), 128.6(2 \mathrm{CH}), 129.0(2 \mathrm{CH}), 129.8(2 \mathrm{CH})$, $129.9(2 \mathrm{CH}), 133.6(\mathrm{C}), 134.3(\mathrm{CH}), 136.2(\mathrm{C}), 136.3(\mathrm{C}), 160.3(\mathrm{C}), 192.6(\mathrm{C}=\mathrm{O})$; HRMS, $m / z$ : 442.1055 found (calcd for $\mathrm{C}_{26} \mathrm{H}_{19}{ }^{35} \mathrm{ClN}_{2} \mathrm{O}_{2}, \mathrm{M}^{+\bullet}$ requires: 442.1084). The minor diastereoisomer $\mathbf{3}$ 'cb was isolated similarly in $10 \%$ yield as a white powder: mp $212{ }^{\circ} \mathrm{C} ;{ }^{1} \mathrm{H}$ $\operatorname{NMR}\left(\mathrm{CDCl}_{3}\right) \delta 3.80(\mathrm{~s}, 3 \mathrm{H}), 4.13(\mathrm{t}, 1 \mathrm{H}, J=10.5 \mathrm{~Hz}, \mathrm{H} 4), 4.97(\mathrm{~d}, 1 \mathrm{H}, J=10.6 \mathrm{~Hz}), 5.32$ $(\mathrm{d}, 1 \mathrm{H}, J=10.5 \mathrm{~Hz}), 6.87(\mathrm{~d}, 2 \mathrm{H}, J=8.5 \mathrm{~Hz}), 7.13-7.28(\mathrm{~m}, 6 \mathrm{H}), 7.53(\mathrm{t}, 2 \mathrm{H}, J=7.6 \mathrm{~Hz})$ $7.68(\mathrm{t}, 1 \mathrm{H}, J=7.2 \mathrm{~Hz}), 7.96(\mathrm{~d}, 2 \mathrm{H}, J=7.8 \mathrm{~Hz})$; HRMS, $m / z: 442.1061$ found (calcd for $\mathrm{C}_{26} \mathrm{H}_{19}{ }^{35} \mathrm{ClN}_{2} \mathrm{O}_{2}, \mathrm{M}^{+\bullet}$ requires: 442.1084). The general procedure 3 (reflux of $20 \mathrm{~h}$ ), using 3(4-methoxyphenyl)oxirane-2,2-dicarbonitrile (1c, $0.40 \mathrm{~g})$ and 4-chlorochalcone (2b, $0.49 \mathrm{~g})$, gave a 75/25 mixture from which the preponderant and minor diastereoisomer 3cb and 3'cb were respectively isolated by chromatography over silica gel (eluent: petrol/AcOEt 90:10) in $45 \%$ and $15 \%$ yield.

\subsection{Diastereoisomers of 4-benzoyl-5-(4-chlorophenyl)-3-(4-}

methoxyphenyl)tetrahydrofuran-2,2-dicarbonitrile. The general procedure 1 (reflux of 38 h), using 3-(4-chlorophenyl)oxirane-2,2-dicarbonitrile (1b, $0.41 \mathrm{~g})$ and 4-methoxychalcone (2c, 0.48 g), gave a 80/20 mixture from which the preponderant diastereoisomer 3bc was isolated by chromatography over silica gel (eluent: $\mathrm{CH}_{2} \mathrm{Cl}_{2} /$ petrol 70:30) in $38 \%$ yield as a white powder: mp $152{ }^{\circ} \mathrm{C} ;{ }^{1} \mathrm{H} \mathrm{NMR}\left(\mathrm{CDCl}_{3}\right) \delta 3.79(\mathrm{~s}, 3 \mathrm{H}), 4.84(\mathrm{~d}, 1 \mathrm{H}, J=11.7 \mathrm{~Hz}, \mathrm{H} 3)$, $5.08(\mathrm{dd}, 1 \mathrm{H}, J=11.8$ and $9.7 \mathrm{~Hz}, \mathrm{H} 4), 5.94(\mathrm{~d}, 1 \mathrm{H}, J=9.7 \mathrm{~Hz}, \mathrm{H} 5), 6.92-6.95(\mathrm{~m}, 4 \mathrm{H}), 7.11-$ $7.15(\mathrm{~m}, 2 \mathrm{H}), 7.41-7.48(\mathrm{~m}, 4 \mathrm{H}), 7.59(\mathrm{tt}, 1 \mathrm{H}, J=7.4$ and $1.2 \mathrm{~Hz}), 7.68-7.71(\mathrm{~m}, 2 \mathrm{H}) ;{ }^{13} \mathrm{C}$ NMR $\left(\mathrm{CDCl}_{3}\right) \delta 53.3(\mathrm{CH}), 55.4\left(\mathrm{CH}_{3}\right), 56.0(\mathrm{CH}), 73.5(\mathrm{C}), 83.6(\mathrm{CH}), 112.4(\mathrm{CN}), 112.9$ $(\mathrm{CN}), 115.0(2 \mathrm{CH}), 121.3(\mathrm{C}), 128.4(2 \mathrm{CH}), 128.4(2 \mathrm{CH}), 128.7(2 \mathrm{CH}), 129.2(2 \mathrm{CH}), 129.6$ 
(2CH), $133.4(\mathrm{C}), 134.4(\mathrm{CH}), 135.3(\mathrm{C}), 136.3(\mathrm{C}), 160.8(\mathrm{C}), 192.6(\mathrm{C}=\mathrm{O})$; HRMS, $m / z$ : 442.1071 found (calcd for $\mathrm{C}_{26} \mathrm{H}_{19}{ }^{35} \mathrm{ClN}_{2} \mathrm{O}_{3}, \mathrm{M}^{+\bullet}$ requires: 442.1084). The general procedure 3 (reflux of $20 \mathrm{~h}$ ), using 3-(4-chlorophenyl)oxirane-2,2-dicarbonitrile (1b, $0.41 \mathrm{~g})$ and 4methoxychalcone (2c, $0.48 \mathrm{~g}$ ), gave a 79/21 mixture from which the preponderant diastereoisomer 3bc was isolated by chromatography over silica gel (eluent: $\mathrm{CH}_{2} \mathrm{Cl}_{2}$ /petrol 70:30) in 45\% yield. The minor diastereoisomer 3'bc was identified by selected NMR data: ${ }^{1} \mathrm{H}$ NMR $\left(\mathrm{CDCl}_{3}\right) \delta 3.99(\mathrm{t}, 1 \mathrm{H}, J=10.5 \mathrm{~Hz}, \mathrm{H} 4), 5.35(\mathrm{~d}, 1 \mathrm{H}, J=10.7 \mathrm{~Hz})$.

\subsection{Diastereoisomers of 4-benzoyl-3,5-di(4-methoxyphenyl)tetrahydrofuran-2,2-}

dicarbonitrile. The general procedure 1 (reflux of $24 \mathrm{~h}$ ), using 3-(4-methoxyphenyl)oxirane2,2-dicarbonitrile (1c, $0.40 \mathrm{~g}$ ) and 4-methoxychalcone (2c, $0.48 \mathrm{~g}$ ), gave a 77/23 mixture from which the preponderant diastereoisomer 3cc was isolated by chromatography over silica gel (eluent: petrol/AcOEt 80:20) in 30\% yield as a yellow oil; ${ }^{1} \mathrm{H} \mathrm{NMR}\left(\mathrm{CDCl}_{3}\right) \delta 3.70(\mathrm{~s}, 3 \mathrm{H})$, $3.78(\mathrm{~s}, 3 \mathrm{H}), 4.89(\mathrm{~d}, 1 \mathrm{H}, J=11.8 \mathrm{~Hz}, \mathrm{H} 3), 5.06(\mathrm{dd}, 1 \mathrm{H}, J=11.8$ and $9.6 \mathrm{~Hz}, \mathrm{H} 4), 5.95(\mathrm{~d}$, $1 \mathrm{H}, J=9.6 \mathrm{~Hz}, \mathrm{H} 5), 6.64-6.67(\mathrm{~m}, 2 \mathrm{H}), 6.92-6.95(\mathrm{~m}, 4 \mathrm{H}), 7.38-7.43(\mathrm{~m}, 2 \mathrm{H}), 7.47-7.50(\mathrm{~m}$, 2H), $7.54(\mathrm{tt}, 1 \mathrm{H}, J=7.4$ and $1.2 \mathrm{~Hz}), 7.68-7.71(\mathrm{~m}, 2 \mathrm{H}) ;{ }^{13} \mathrm{C} \mathrm{NMR}\left(\mathrm{CDCl}_{3}\right) \delta 53.4(\mathrm{CH})$, $55.3\left(\mathrm{CH}_{3}\right), 55.4\left(\mathrm{CH}_{3}\right), 56.0(\mathrm{CH}), 73.3(\mathrm{C}), 84.2(\mathrm{CH}), 112.6(\mathrm{CN}), 113.1(\mathrm{CN}), 113.7$ $(2 \mathrm{CH}), 114.9(2 \mathrm{CH}), 121.8(\mathrm{C}), 126.8(\mathrm{C}), 128.4(2 \mathrm{CH}), 128.6(2 \mathrm{CH}), 128.9(2 \mathrm{CH}), 129.6$ (2CH), $134.1(\mathrm{CH}), 136.4(\mathrm{C}), 160.1(\mathrm{C}), 160.7(\mathrm{C}), 192.9(\mathrm{C}=\mathrm{O})$; HRMS, m/z: 438.1583 found (calcd for $\mathrm{C}_{27} \mathrm{H}_{22} \mathrm{~N}_{2} \mathrm{O}_{4}, \mathrm{M}^{+\bullet}$ requires: 438.1580). The general procedure 3 (reflux of 18 h), using 3-(4-methoxyphenyl)oxirane-2,2-dicarbonitrile (1c, 0.40 g) and 4-methoxychalcone (2c, only $0.24 \mathrm{~g}$ ), gave a 72/28 mixture from which the preponderant diastereoisomer 3cc was isolated by chromatography over silica gel (eluent: petrol/AcOEt 80:20) in $48 \%$ yield. The minor diastereoisomer 3'cc was identified by selected NMR data: ${ }^{1} \mathrm{H}$ NMR $\left(\mathrm{CDCl}_{3}\right) \delta 4.07(\mathrm{t}$, $1 \mathrm{H}, J=10.5 \mathrm{~Hz}, \mathrm{H} 4), 5.33(\mathrm{~d}, 1 \mathrm{H}, J=10.5 \mathrm{~Hz})$. 


\subsection{Diastereoisomers of 3-(4-chlorophenyl)-4-oxohexahydro-1H-cyclopenta[c]furan-}

1,1-dicarbonitrile. The general procedure 1 (reflux of $48 \mathrm{~h}$ ), using 3-(4chlorophenyl)oxirane-2,2-dicarbonitrile (1b, $0.41 \mathrm{~g})$ and 2-cyclopentenone (4, $0.16 \mathrm{~g})$, gave a 60/40 mixture from which the preponderant diastereoisomer $\mathbf{5 b}$ was isolated by chromatography over silica gel (eluent: heptane/ $\mathrm{Et}_{2} \mathrm{O}$ 70:30) in $45 \%$ yield as a beige powder: mp $109{ }^{\circ} \mathrm{C} ;{ }^{1} \mathrm{H}$ NMR $\left(\mathrm{CDCl}_{3}\right) \delta$ 2.18-2.45 (m, 4H), $3.36(\mathrm{t}, 1 \mathrm{H}, J=8.6 \mathrm{~Hz}, \mathrm{H} 4), 3.68-3.81$ (m, 1H, H3), $5.52(\mathrm{~d}, 1 \mathrm{H}, J=9.1 \mathrm{~Hz}, \mathrm{H} 5), 7.17(\mathrm{~d}, 2 \mathrm{H}, J=8.0 \mathrm{~Hz}), 7.36(\mathrm{~d}, 2 \mathrm{H}, J=8.1 \mathrm{~Hz})$; ${ }^{13} \mathrm{C}$ NMR $\left(\mathrm{CDCl}_{3}\right) \delta 24.9\left(\mathrm{CH}_{2}\right), 38.5\left(\mathrm{CH}_{2}\right), 52.6(\mathrm{CH}), 54.5(\mathrm{CH}), 71.7(\mathrm{C}), 84.7(\mathrm{CH})$, $111.3(\mathrm{CN}), 113.1(\mathrm{CN}), 127.3(2 \mathrm{CH}), 129.1(2 \mathrm{CH}), 131.6(\mathrm{C}), 135.1(\mathrm{C}), 210.6(\mathrm{C}=\mathrm{O})$; HRMS, $m / z: 286.0514$ found (calcd for $\mathrm{C}_{15} \mathrm{H}_{11}{ }^{35} \mathrm{ClN}_{2} \mathrm{O}_{2}, \mathrm{M}^{+\bullet}$ requires: 286.0509). The minor diastereoisomer $\mathbf{5}^{\mathbf{5}} \mathbf{b}$ was isolated similarly in $23 \%$ yield as a white powder: mp $144{ }^{\circ} \mathrm{C} ;{ }^{1} \mathrm{H}$ $\operatorname{NMR}\left(\mathrm{CDCl}_{3}\right) \delta 2.28-2.38(\mathrm{~m}, 1 \mathrm{H}), 2.53-2.63(\mathrm{~m}, 2 \mathrm{H}), 2.77-2.86(\mathrm{~m}, 1 \mathrm{H}), 3.24(\mathrm{t}, 1 \mathrm{H}, J=7.8$ Hz, H4), 3.81 (q, 1H, $J=7.9 \mathrm{~Hz}, \mathrm{H} 3), 5.34(\mathrm{~d}, 1 \mathrm{H}, J=6.7 \mathrm{~Hz}, \mathrm{H} 5), 7.33$ (d, 2H, $J=8.6 \mathrm{~Hz})$, $7.39(\mathrm{~d}, 2 \mathrm{H}, J=8.7 \mathrm{~Hz}) ;{ }^{13} \mathrm{C} \mathrm{NMR}\left(\mathrm{CDCl}_{3}\right) \delta 23.2\left(\mathrm{CH}_{2}\right), 37.9\left(\mathrm{CH}_{2}\right), 54.2(\mathrm{CH}), 58.9(\mathrm{CH})$, $71.8(\mathrm{C}), 84.5(\mathrm{CH}), 111.8(\mathrm{CN}), 113.5(\mathrm{CN}), 127.0(2 \mathrm{CH}), 129.3(2 \mathrm{CH}), 135.0(\mathrm{C}), 135.9$ (C), $211.5(\mathrm{C}=\mathrm{O})$; HRMS, $m / z: 286.0520$ found (calcd for $\mathrm{C}_{15} \mathrm{H}_{11}{ }^{35} \mathrm{ClN}_{2} \mathrm{O}_{2}, \mathrm{M}^{+\bullet}$ requires: 286.0509). The general procedure 3 (reflux of $24 \mathrm{~h}$ ), using 3-(4-chlorophenyl)oxirane-2,2dicarbonitrile (1b, $0.41 \mathrm{~g})$ and 2-cyclopentenone (4, $0.16 \mathrm{~g})$, gave a 57/43 mixture from which the preponderant diastereoisomer $\mathbf{5 b}$ was isolated by chromatography over silica gel (eluent: heptane/Et $2 \mathrm{O} 70: 30$ ) in 50\% yield.

\subsection{Diastereoisomers of 4-oxo-3-phenylhexahydro-1H-cyclopenta[ $[c]$ furan-1,1-} dicarbonitrile. The general procedure 1 (reflux of $46 \mathrm{~h}$ ), using 3-phenyloxirane-2,2dicarbonitrile (1a, $0.34 \mathrm{~g})$ and 2-cyclopentenone (4, 0.16 g), gave a 59/41 mixture from which the preponderant diastereoisomer 5a was isolated by chromatography over silica gel (eluent: heptane/ $\left.\mathrm{Et}_{2} \mathrm{O} 70: 30\right)$ in $51 \%$ yield as a beige powder: $\mathrm{mp} 158{ }^{\circ} \mathrm{C} ;{ }^{1} \mathrm{H} \mathrm{NMR}\left(\mathrm{CDCl}_{3}\right) \delta 2.18$ - 
$2.48(\mathrm{~m}, 4 \mathrm{H}), 3.36(\mathrm{t}, 1 \mathrm{H}, J=8.8 \mathrm{~Hz}, \mathrm{H} 4), 3.72(\mathrm{q}, 1 \mathrm{H}, J=7.6 \mathrm{~Hz}, \mathrm{H} 3), 5.55(\mathrm{~d}, 1 \mathrm{H}, J=9.3$ $\mathrm{Hz}, \mathrm{H} 5)$, 7.22-7.24 (m, 2H), 7.35-7.42 (m, 3H); ${ }^{13} \mathrm{C} \mathrm{NMR}\left(\mathrm{CDCl}_{3}\right) \delta 24.8\left(\mathrm{CH}_{2}\right), 38.5\left(\mathrm{CH}_{2}\right)$, $52.7(\mathrm{CH}), 54.7(\mathrm{CH}), 71.7(\mathrm{C}), 85.5(\mathrm{CH}), 111.4(\mathrm{CN}), 113.3(\mathrm{CN}), 125.9(2 \mathrm{CH}), 128.9$ (2CH), $129.3(\mathrm{CH}), 133.1(\mathrm{C}), 210.8(\mathrm{C}=\mathrm{O})$; HRMS, m/z: 252.0912 found (calcd for $\mathrm{C}_{15} \mathrm{H}_{12} \mathrm{~N}_{2} \mathrm{O}_{2}, \mathrm{M}^{+\bullet}$ requires: 252.0899). Crystal data for 5a (CCDC 688217). $\mathrm{C}_{15} \mathrm{H}_{12} \mathrm{~N}_{2} \mathrm{O}_{2}, M$ $=252.27$, orthorhombic, $P b c a, a=7.9165(4), b=13.9702(9), c=21.5846(13) \AA, V=$ 2387.2(2) $\AA^{3}, Z=8, d=1.404 \mathrm{~g} \mathrm{~cm}^{-3}, \mu=0.095 \mathrm{~mm}^{-1}$. A final refinement on $F^{2}$ with 2739 unique intensities and 172 parameters converged at $\omega R\left(F^{2}\right)=0.1034(R(F)=0.0477)$ for 2703 observed reflections with $I>2 \sigma(I)$. The minor diastereoisomer 5'a was identified by selected NMR data: ${ }^{1} \mathrm{H}$ NMR $\left(\mathrm{CDCl}_{3}\right) \delta 5.38(\mathrm{~d}, 1 \mathrm{H}, J=6.7 \mathrm{~Hz}, \mathrm{H} 5)$.

\subsection{Diastereoisomers of 3-(4-methoxyphenyl)-4-oxohexahydro-1H-}

cyclopenta[c]furan-1,1-dicarbonitrile. The general procedure 1 (reflux of $25 \mathrm{~h}$ ), using 3-(4methoxyphenyl)oxirane-2,2-dicarbonitrile (1c, $0.40 \mathrm{~g})$ and 2-cyclopentenone (4, $0.16 \mathrm{~g})$, gave a 57/43 mixture from which the minor diastereoisomer 5'c was isolated by chromatography over silica gel (eluent: heptane/Et $2 \mathrm{O} 70: 30)$ in $23 \%$ yield as a beige oil; ${ }^{1} \mathrm{H} \mathrm{NMR}\left(\mathrm{CDCl}_{3}\right) \delta$ 2.34-2.40 (m, 1H), 2.52-2.59 (m, 2H), 2.76-2.85 (m, 1H), $3.28(\mathrm{~s}, 3 \mathrm{H}, \mathrm{OMe}), 5.32(\mathrm{~d}, 1 \mathrm{H}, J=$ $6.6 \mathrm{~Hz}), 6.93(\mathrm{~d}, 2 \mathrm{H}, J=8.7 \mathrm{~Hz}), 7.30(\mathrm{~d}, 2 \mathrm{H}, J=8.7 \mathrm{~Hz}) ;{ }^{13} \mathrm{C} \mathrm{NMR}\left(\mathrm{CDCl}_{3}\right) \delta 23.5\left(\mathrm{CH}_{2}\right)$, $37.8\left(\mathrm{CH}_{2}\right), 54.5(\mathrm{CH}), 55.5(\mathrm{OMe}), 58.9(\mathrm{CH}), 71.7(\mathrm{C}), 85.5(\mathrm{CH}), 113.8(\mathrm{CN}), 114.6$ (2CH), $115.5(\mathrm{CN}), 127.4(2 \mathrm{CH}), 129.0(\mathrm{C}), 160.3(\mathrm{C}), 212.2(\mathrm{C}=\mathrm{O})$; HRMS, $m / z: 282.1020$ found (calcd for $\mathrm{C}_{16} \mathrm{H}_{14} \mathrm{~N}_{2} \mathrm{O}_{3}, \mathrm{M}^{+\bullet}$ requires: 282.1004). The general procedure 3 (reflux of 18 h), using 3-(4-methoxyphenyl)oxirane-2,2-dicarbonitrile (1c, 0.40 g) and 2-cyclopentenone (4, $0.16 \mathrm{~g}$ ), gave a 62/38 mixture from which the minor diastereoisomer 5'c was isolated by chromatography over silica gel (eluent: heptane/ $\operatorname{Et}_{2} \mathrm{O} 70: 30$ ) in $29 \%$ yield. The major diastereoisomer 5c was identified by selected NMR data: ${ }^{1} \mathrm{H}$ NMR $\left(\mathrm{CDCl}_{3}\right) \delta 5.51(\mathrm{~d}, 1 \mathrm{H}, J=$ $9.3 \mathrm{~Hz})$. 


\subsection{Diastereoisomers of 5-(4-chlorophenyl)-3-cyano-3-morpholinotetrahydrofuran-}

2,2-dicarbonitrile. The general procedure 4 (reflux of 46 h), using 3-(4chlorophenyl)oxirane-2,2-dicarbonitrile (1b, $0.41 \mathrm{~g})$, gave a 55/45 mixture from which the preponderant diastereoisomer $\mathbf{1 0 b}$ was isolated by recrystallization in $\mathrm{EtOH}$ in $50 \%$ yield as a white powder: $\mathrm{mp} 191{ }^{\circ} \mathrm{C} ;{ }^{1} \mathrm{H}$ NMR $\left(\mathrm{CDCl}_{3}\right) \delta$ 2.70-2.87 (m, 5H), $3.00(\mathrm{dd}, 1 \mathrm{H}, J=13.4$ and $9.7 \mathrm{~Hz}, \mathrm{H} 4), 3.77-3.94(\mathrm{~m}, 4 \mathrm{H}), 5.53(\mathrm{dd}, 1 \mathrm{H}, J=9.6$ and $4.8 \mathrm{~Hz}, \mathrm{H} 5), 7.33-7.45(\mathrm{~m}, 4 \mathrm{H}) ;{ }^{13} \mathrm{C}$ NMR $\left(\mathrm{CDCl}_{3}\right) \delta 43.4\left(\mathrm{CH}_{2}\right), 50.4\left(2 \mathrm{CH}_{2}\right), 66.0\left(2 \mathrm{CH}_{2}\right), 74.9(\mathrm{C}), 75.0(\mathrm{C}), 81.4(\mathrm{CH}), 109.6$ $(\mathrm{CN}), 110.8(\mathrm{CN}), 113.2(\mathrm{CN}), 127.6(2 \mathrm{CH}), 129.6(2 \mathrm{CH}), 135.2(\mathrm{C}), 135.8(\mathrm{C}) ; \mathrm{HRMS}, m / z$ : 340.0715 found (calcd for $\mathrm{C}_{17} \mathrm{H}_{13}{ }^{35} \mathrm{ClN}_{4} \mathrm{O}_{2}, \mathrm{M}^{+\cdot}$ requires: 340.0727). The minor diastereoisomer 10'b was identified by selected NMR data: ${ }^{1} \mathrm{H}$ NMR $\left(\mathrm{CDCl}_{3}\right) \delta 5.63(\mathrm{dd}, 1 \mathrm{H}$, $J=11.5$ and $4.9 \mathrm{~Hz}, \mathrm{H} 5)$.

\subsection{Diastereoisomers of 3-cyano-3-morpholino-5-phenyltetrahydrofuran-2,2-} dicarbonitrile. The general procedure 4 (reflux of $37 \mathrm{~h}$ ), using 3-phenyloxirane-2,2dicarbonitrile (1a, $0.34 \mathrm{~g}$ ), gave a 50/50 mixture from which the diastereoisomer 10a was isolated by recrystallization in $\mathrm{EtOH}$ in $37 \%$ yield as a beige powder: mp $188{ }^{\circ} \mathrm{C}$; ${ }^{1} \mathrm{H} \mathrm{NMR}$ $\left(\mathrm{CDCl}_{3}\right) \delta 2.70-2.87(\mathrm{~m}, 5 \mathrm{H}), 2.99(\mathrm{dd}, 1 \mathrm{H}, J=13.4$ and $9.6 \mathrm{~Hz}, \mathrm{H} 4), 3.77-3.92(\mathrm{~m}, 4 \mathrm{H}), 5.54$ $(\mathrm{dd}, 1 \mathrm{H}, J=9.6$ and $5.0 \mathrm{~Hz}, \mathrm{H} 5), 7.36-7.50(\mathrm{~m}, 5 \mathrm{H}) ;{ }^{13} \mathrm{C} \mathrm{NMR}\left(\mathrm{CDCl}_{3}\right) \delta 43.4\left(\mathrm{CH}_{2}\right), 50.4$ $\left(2 \mathrm{CH}_{2}\right), 66.1\left(2 \mathrm{CH}_{2}\right), 74.8(\mathrm{C}), 75.0(\mathrm{C}), 82.2(\mathrm{CH}), 109.7(\mathrm{CN}), 111.0(\mathrm{CN}), 113.3(\mathrm{CN})$, $124.7(\mathrm{CH}), 127.8(2 \mathrm{CH}), 131.0(2 \mathrm{CH}), 131.5(\mathrm{C})$; HRMS, $\mathrm{m} / z: 306.1111$ found (calcd for $\mathrm{C}_{17} \mathrm{H}_{14} \mathrm{~N}_{4} \mathrm{O}_{2}, \mathrm{M}^{+\bullet}$ requires: 306.1117).

\subsection{Diastereoisomers of 3-cyano-5-(4-methoxyphenyl)-3-}

morpholinotetrahydrofuran-2,2-dicarbonitrile. The general procedure 4 (reflux of $20 \mathrm{~h}$ ), using 3-(4-methoxyphenyl)oxirane-2,2-dicarbonitrile (1c, $0.40 \mathrm{~g}$ ), gave a 95/5 mixture from which the preponderant diastereoisomer 10c was isolated by recrystallization in $\mathrm{EtOH}$ in $62 \%$ yield as a yellow powder: $\mathrm{mp} 151{ }^{\circ} \mathrm{C} ;{ }^{1} \mathrm{H}$ NMR $\left(\mathrm{CDCl}_{3}\right) \delta 2.75-2.84(\mathrm{~m}, 5 \mathrm{H}), 2.94(\mathrm{dd}, 1 \mathrm{H}, J$ 
$=13.4$ and $9.7 \mathrm{~Hz}, \mathrm{H} 4), 3.83-3.89(\mathrm{~m}, 4 \mathrm{H}), 5.48(\mathrm{dd}, 1 \mathrm{H}, J=9.5$ and $5.1 \mathrm{~Hz}, \mathrm{H} 5), 6.95-6.96$ (m, 2H), 7.35-7.37 (m, 2H); ${ }^{13} \mathrm{C}$ NMR $\left(\mathrm{CDCl}_{3}\right) \delta 43.4\left(\mathrm{CH}_{2}\right), 50.4\left(2 \mathrm{CH}_{2}\right), 55.5\left(\mathrm{CH}_{3}\right), 66.1$ $\left(2 \mathrm{CH}_{2}\right), 74.7(\mathrm{C}), 75.3(\mathrm{C}), 82.2(\mathrm{CH}), 109.8(\mathrm{CN}), 111.0(\mathrm{CN}), 113.5(\mathrm{CN}), 114.7(2 \mathrm{CH})$, $128.2(2 \mathrm{CH}), 128.4(\mathrm{C}), 160.8(\mathrm{C})$; HRMS, $m / z$ : 336.1205 found (calcd for $\mathrm{C}_{18} \mathrm{H}_{16} \mathrm{~N}_{4} \mathrm{O}_{3}, \mathrm{M}^{+}$ requires: 336.1222). The minor diastereoisomer 10'c was identified by selected NMR data: ${ }^{1} \mathrm{H}$ $\operatorname{NMR}\left(\mathrm{CDCl}_{3}\right) \delta 5.67(\mathrm{dd}, 1 \mathrm{H}, J=11.5$ and $4.8 \mathrm{~Hz}, \mathrm{H} 5)$.

\subsection{Diastereoisomers of 3-cyano-3-morpholino-5-(4-nitrophenyl)tetrahydrofuran-}

2,2-dicarbonitrile. The general procedure 4 (but using xylene, reflux of $38 \mathrm{~h}$ ), using 3-(4nitrophenyl)oxirane-2,2-dicarbonitrile (1d, $0.43 \mathrm{~g}$ ), gave a 62/38 mixture from which the preponderant diastereoisomer 10d was isolated by recrystallization in $\mathrm{EtOH}$ in $45 \%$ yield as a beige powder: $\mathrm{mp} 228{ }^{\circ} \mathrm{C} ;{ }^{1} \mathrm{H} \mathrm{NMR}\left(\left(\mathrm{CD}_{3}\right)_{2} \mathrm{CO}\right) \delta 2.56-2.66(\mathrm{~m}, 5 \mathrm{H}), 3.02(\mathrm{dd}, 1 \mathrm{H}, J=14.1$ and $4.1 \mathrm{~Hz}, \mathrm{H} 4), 3.15(\mathrm{dd}, 1 \mathrm{H}, J=14.1$ and $9.9 \mathrm{~Hz}, \mathrm{H} 4), 3.49-3.58(\mathrm{~m}, 4 \mathrm{H}), 5.64(\mathrm{dd}, 1 \mathrm{H}, J=$ 9.8 and 4.0 Hz, H5), 7.23-7.25 (m, 2H), 7.75-7.76 (m, 2H); selected ${ }^{1} \mathrm{H}$ NMR $\left(\mathrm{CDCl}_{3}\right) \delta 5.70$ $(\mathrm{dd}, 1 \mathrm{H}, J=9.85$ and $4.0 \mathrm{~Hz}, \mathrm{H} 5) ;{ }^{13} \mathrm{C} \mathrm{NMR}\left(\left(\mathrm{CD}_{3}\right)_{2} \mathrm{CO}\right) \delta 43.1\left(\mathrm{CH}_{2}\right), 51.2\left(2 \mathrm{CH}_{2}\right), 66.6$ $\left(2 \mathrm{CH}_{2}\right), 75.8(\mathrm{C}), 76.1(\mathrm{C}), 82.2(\mathrm{CH}), 110.7(\mathrm{CN}), 112.3(\mathrm{CN}), 114.0(\mathrm{CN}), 124.7(2 \mathrm{CH})$, 127.9 (2CH), 145.8 (C), 149.2 (C); HRMS, m/z: 351.0972 found (calcd for $\mathrm{C}_{17} \mathrm{H}_{13} \mathrm{~N}_{5} \mathrm{O}_{4}, \mathrm{M}^{+}$ requires: 351.0968). The minor diastereoisomer 10'd was identified by selected NMR data: ${ }^{1} \mathrm{H}$ NMR $\left(\mathrm{CDCl}_{3}\right) \delta 5.78(\mathrm{dd}, 1 \mathrm{H}, J=11.4$ and $5.2 \mathrm{~Hz}, \mathrm{H} 5)$.

\subsection{Computational methods}

Density functional theory (DFT) calculations were carried out using the MPWB1K functional $^{32}$ together with the standard 6-311G(d) basis set. ${ }^{33}$ Optimizations were carried out using the Berny analytical gradient optimization method. ${ }^{34}$ The stationary points were characterized by frequency calculations to verify that the transition state structures (TSs) have one and only one imaginary frequency. The IRC paths ${ }^{35}$ were traced in order to check the energy profiles connecting each TS to the two associated minima of the proposed mechanism 
using the second order González-Schlegel integration method. ${ }^{36}$ Solvent effects of toluene were taken into account by full optimization of the gas phase geometries using the polarisable continuum model (PCM) developed by Tomasi's group ${ }^{37}$ in the framework of the selfconsistent reaction field (SCRF). ${ }^{38}$ Values of enthalpies, entropies and Gibbs free energies in toluene were calculated with the standard statistical thermodynamics at $386 \mathrm{~K}$ and $1 \mathrm{~atm}^{33}$ The Global Electron Density Transfer (GEDT) ${ }^{22}$ is computed by the sum of the natural atomic charges (q), obtained by a natural population analysis (NPA) $)^{39}$ of the atoms belonging to each framework (f) at the TSs; GEDT $=\Sigma q_{f}$. The sign indicates the direction of the electron density flux in such a manner that positive values mean a flux from the considered framework to the other one. All the computations were carried out with the Gaussian 09 suite of programs. ${ }^{40}$

The $\mathrm{ELF}^{41}$ analyses were performed with the TopMod program, ${ }^{42}$ using the corresponding MPWB1K/6-311G(d) monodeterminantal wave functions over a grid spacing of 0.1 a.u.. For the bonding evolution theory study, the corresponding reaction channel was followed by performing the topological analysis of the ELF for 519 nuclear configurations along the IRC path.

\section{Acknowledgements}

The experimental study has been supported by the Centre National de la Recherche Scientifique, the Université de Rennes 1, the Institut Universitaire de France, Rennes Métropole, the Ministère de l'Enseignement supérieur, de la Recherche et de l'Innovation, and Région Lorraine. The theoretical study has been supported by the Ministry of Economy and Competitiveness (MINECO) of the Spanish Government, project CTQ2016-78669-P (AEI/FEDER, UE). M.R.-G. thanks MINECO for a pre-doctoral contract co-financed by the European Social Fund (BES-2014-068258). We also thank the Cancéropôle Grand Ouest (axis: natural sea products in cancer treatment), IBiSA (French Infrastructures en sciences du 
vivant: biologie, santé et agronomie) and Biogenouest (Western France life science and environment core facility network) for supporting KISS $f$ screening facility. FM thanks Dr. Keith Woerpel for helpful discussions.

\section{Supplementary data}

Supplementary data associated with this article can be found, in the online version, at http://dx.doi.org/10.1016/xxxxxxxxxxxxxxxxxxxxxxxx. It contains ${ }^{1} \mathrm{H}$ and ${ }^{13} \mathrm{C}$ NMR spectra of the new compounds, details of the theoretical calculations and of the biological evaluation.

\section{References and notes}

1. Lorente, A.; Lamariano-Merketegi, J.; Albericio, F.; Álvarez, M. Chem. Rev. 2013, 113, 4567-4610.

2. Rainier, J. D. Top. Heterocycl. Chem. 2014, 35, 1-41.

3. (a) Huisgen, R.; Grashey, R.; Sauer, J. The Chemistry of Alkenes 1964, Interscience, New York; (b) Sustmann, R. Heterocycles 1995, 40, 1-18.

4. (a) Chiacchio, U.; Padwa, A.; Romeo, G. Curr. Org. Chem. 2009, 13, 422-447; (b) Zhang, W. Chem. Lett. 2013, 42, 676-681.

5. (a) Padwa, A. 1,3-Dipolar Cycloaddition Chemistry 1984, Wiley-Interscience, New York, vol. 1-2; (b) Gothelf, K. V.; Jorgensen, K. A. Chem. Rev. 1998, 98, 863-909.

6. (a) Robert, A.; Pommeret, J. J.; Foucaud, A. C. R. Acad. Sci. Paris, Ser. C 1970, 270, 1739-1742; (b) Pommeret, J. J.; Robert, A. Tetrahedron 1971, 27, 2977-2987; (c) Derdour, A.; Texier, F. Can. J. Chem. 1985, 63, 2245-2252; (d) Clawson, P.; Lunn, P. M.; Whiting, D. A. J. Chem. Soc., Perkin Trans. 1 1990, 159-162; (e) Ruf, S. G.; Dietz, J.; Regitz, M. Tetrahedron 2000, 56, 6259-6267; (f) Liu, R.; Zhang, M.; Zhang, J. Chem. Commun. 2011, 47, 12870-12872; (g) Bentabed-Ababsa, G.; Hamza-Reguig, S.; Derdour, A.; Domingo, L. R.; Saez, J. A.; Roisnel, T.; Dorcet, V.; Nassar, E.; Mongin, F. Org. Biomol. Chem. 2012, 10, 8434-8444; (h) Chen, W.; Fu, X.; Lin, L.; Yuan, X.; Luo, W.; Feng, J.; Liu, X.; Feng, X. Chem. Commun. 2014, 50, 1148011483.

7. (a) Bentabed, G.; Derdour, A.; Benhaoua, H. Synth. Commun. 2003, 33, 1861-1866;

(b) Yoakim, C.; Goudreau, N.; McGibbon, G. A.; O'Meara, J.; White, P. W.; Ogilvie, W. W. Helv. Chim. Acta 2003, 86, 3427-3444; (c) Tagliapietra, S.; Cravotto, G.; Gaudino, E. C.; Visentin, S.; Mussi, V. Synlett 2012, 23, 1459-1462; (d) Yuan, X.; Lin, L.; Chen, W.; Wu, W.; Liu, X.; Feng, X. J. Org. Chem. 2016, 81, 1237-1243.

8. (a) Pommeret, J. J.; Robert, A. C. R. Acad. Sci. Paris, Ser. C 1971, 272, 333-336; (b) Robert, A.; Pommeret, J. J.; Marchand, E.; Foucard, A. Tetrahedron 1973, 29, 463468; (c) Bentabed, G.; Rahmouni, M.; Mongin, F.; Derdour, A.; Hamelin, J.; Bazureau, J. P. Synth. Commun. 2007, 37, 2935-2948; (d) Bentabed-Ababsa, G.; Derdour, A.; Roisnel, T.; Saez, J. A.; Pérez, P.; Chamorro, E.; Domingo, L. R.; Mongin, F. J. Org. Chem. 2009, 2120-2133. 
9. (a) Robert, A.; Pommeret, J. J.; Foucaud, A. Tetrahedron Lett. 1971, 231-234; (b) Robert, A.; Pommeret, J. J.; Foucaud, A. Tetrahedron 1972, 28, 2085-2097; (c) Chen, Z.; Wei, L.; Zhang, J. Org. Lett. 2011, 13, 1170-1173; (d) Chen, W.; Lin, L.; Cai, Y.; Xia, Y.; Cao, W.; Liu, X.; Feng, X. Chem. Commun. 2014, 50, 2161-2163.

10. Bentabed-Ababsa, G.; Derdour, A.; Roisnel, T.; Saez, J. A.; Domingo, L. R.; Mongin, F. Org. Biomol. Chem. 2008, 6, 3144-3157.

11. Meier, K. R.; Linden, A.; Mloston, G.; Heimgartner, H. Helv. Chim. Acta 1997, 80, 1190-1204.

12. Domingo, L. R.; Aurell, M. J.; Pérez, P. Tetrahedron 2015, 71, 1050-1057.

13. Bougrin, K.; Benhida, R. Microwaves in Organic Synthesis (3rd Edition) 2012, 2, 737-809.

14. Using a monomode reactor (Prolabo Synthewave 402) with accurate control of power and temperature (infrared detection).

15. Heravi, M. M.; Tamimi, M.; Yahyavi, H.; Hosseinnejad, T. Curr. Org. Chem. 2016, 20, 1591-1647.

16. (a) Smith, D. M.; Woerpel, K. A. Org. Lett. 2004, 6, 2063-2066; (b) Shenoy, S. R.; Smith, D. M.; Woerpel, K. A. J. Am. Chem. Soc. 2006, 128, 8671-8677; (c) Parsons, A. T.; Johnson, J. S. J. Am. Chem. Soc. 2009, 131, 3122-3123.

17. Dilman, A. D.; Belyakov, P. A.; Struchkova, M. I.; Arkhipov, D. E.; Korlyukov, A. A.; Tartakovsky, V. A. J. Org. Chem. 2010, 75, 5367-5370.

18. Domingo, L. R. Molecules 2016, 21, 1319-1333.

19. (a) Domingo, L. R.; Emamian, S. R. Tetrahedron 2014, 70, 1267-1273; (b) Domingo, L. R.; Ríos-Gutiérrez, M. Molecules 2017, 22, 750-769.

20. Domingo, L. R.; Ríos-Gutiérrez, M.; Pérez, P. Tetrahedron 2016, 72, 1524-1532.

21. Krokidis, X.; Noury, S.; Silvi, B. J. Phys. Chem. A 1997, 101, 7277-7282.

22. Domingo, L. R. RSC Adv. 2014, 4, 32415-32428.

23. Parr, R. G.; von Szentpaly, L.; Liu, S. J. Am. Chem. Soc. 1999, 121, 1922-1924.

24. Domingo, L. R.; Chamorro, E.; Pérez, P. J. Org. Chem. 2008, 73, 4615-4624.

25. (a) Berski, S.; Andrés, J.; Silvi, B.; Domingo, L. R. J. Phys. Chem. A 2003, 107, 60146024; (b) Polo, V.; Andrés, J.; Berski, S.; Domingo, L. R.; Silvi, B. J. Phys. Chem. A 2008, 112, 7128-7136.

26. Houk, K. N.; González, J.; Li, Y. Acc. Chem. Res. 1995, 28, 81-90.

27. Gottlieb, H. E.; Kotlyar, V.; Nudelman, A. J. Org. Chem. 1997, 62, 7512-7515.

28. Boucher, J. L.; Stella, L. Tetrahedron 1985, 41, 875-887.

29. Altomare, A.; Burla, M. C.; Camalli, M.; Cascarano, G. L.; Giacovazzo, C.; Guagliardi, A.; Moliterni, A. G. G.; Polidori, G.; Spagna, R. J. Appl. Crystallogr. 1999, 32, 115-119.

30. Sheldrick, G. M. Acta Crystallogr., Sect. A 2008, A64, 112-122.

31. Farrugia, L. J. J. Appl. Crystallogr. 2012, 45, 849-854.

32. Zhao, Y.; Truhlar, D. G. J. Phys. Chem. A 2004, 108, 6908-6918.

33. Hehre, W. J.; Radom, L.; Schleyer, P. v. R.; Pople, J. A. Ab initio Molecular Orbital Theory 1986, Wiley: New York.

34. (a) Schlegel, H. B. J. Comput. Chem. 1982, 3, 214-218; (b) Schlegel, H. B. Modern Electronic Structure Theory 1994, Ed.: D. R. Yarkony; World Scientific Publishing: Singapore.

35. Fukui, K. J. Phys. Chem. 1970, 74, 4161-4163.

36. (a) González, C.; Schlegel, H. B. J. Phys. Chem. 1990, 94, 5523-5527; (b) González, C.; Schlegel, H. B. J. Chem. Phys. 1991, 95, 5853-5860. 
37. (a) Tomasi, J.; Persico, M. Chem. Rev. 1994, 94, 2027-2094; (b) Simkin, B. Y.; Sheikhet, I. Quantum Chemical and Statistical Theory of Solutions - Computational Approach 1995, Ellis Horwood, London.

38. (a) Cances, E.; Mennucci, B.; Tomasi, J. J. Chem. Phys. 1997, 107, 3032-3041; (b) Cossi, M.; Barone, V.; Cammi, R.; Tomasi, J. Chem. Phys. Lett. 1996, 255, 327-335;

(c) Barone, V.; Cossi, M.; Tomasi, J. J. Comput. Chem. 1998, 19, 404-417.

39. (a) Reed, A. E.; Weinstock, R. B.; Weinhold, F. J. Chem. Phys. 1985, 83, 735-746; (b) Reed, A. E.; Curtiss, L. A.; Weinhold, F. Chem. Rev. 1988, 88, 899-926.

40. Frisch, M. J., Gaussian 09, Revision A.02, Gaussian Inc., Wallingford CT.

41. Becke, A. D.; Edgecombe, K. E. J. Chem. Phys. 1990, 92, 5397-5403.

42. Noury, S.; Krokidis, X.; Fuster, F.; Silvi, B. Comput. Chem. 1999, 23, 597-604. 